\title{
RECENT DEVELOPMENT OF EXPRESS LOCOMOTIVES IN FRANCE.
}

\author{
By Professetr EDOUARd SAUVAGE, \\ Member, of PARIs.
}

Two Papers on French locomotives by the author of the present one had the honour of discussion at the Meetings of the Institution, one in 1900, on "Recent Locomotive Practice in France," * and the other, in 1904, on "Compound Locomotives in France." $\dagger$ This third Paper, dealing with the further development, during the last decade, in the construction of locomotives for express service on French railways, has been prepared in accordance with the Council's desire. For the data and results of experience reported in this Paper, the author is indebted to the following chief engineers: M. Lancrenon, of the Est; M. Maréchal, of the Paris-LyonMéditerranée; M. Nadal, of the State; M. Asselin, of the Nord; M. Solacroup, of the Paris-Orléans; and M. Herdner, of the Midi Railways, who with the greatest liberality provided him with all the necessary information.

With the exception of some Atlantics, which are not likely to be reproduced, all engines built for this service since 1904 are six-coupled, either ten-wheelers (4-6) or Pacifies (4-6-2). Superheated steam is largely used, specially in the latest constructions. With a few exceptions, the Schmidt standard

$$
\begin{aligned}
& \text { * Proceedings, I.Mech.E., 1900, page } 375 . \\
& \text { † Ibid, 1904, page } 327 .
\end{aligned}
$$

[The '.M.Mech.E.] 
superheater* has been adopted. Owing to the large tubes necessary to receive the superheating pipes, it frequently happens when a superheater is fitted in a locomotive boiler that the proper heating or vaporizing surface is greatly curtailed; in many engines the total of the heating and superheating surfaces is less than the heating surface which might have been obtained without superheating. The figures in Table 1 give some examples of this reduction. $\uparrow$

Without superheaters, the heating surface equals 72 to 77 times the grate area in the first four engines (narrow fire-boxes), and 60 to 62 times in the case of the last (wide fire-boxes). With superheaters, the ratio of proper heating surface to grate area is as low as 50 and does not exceed 60 ; and, with the exception of the two last engines and of Nos. 2601-2605 Paris-Lyon-Méditerranée, the total surface is reduced. Although the results in service are good in all cases of superheating, this large reduction of heating surface in some boilers cannot be entirely satisfactory. $\neq$

No difficulty is reported to arise from the use of superheaters; they are easily kept in order ; valves and pistons, properly lubricated with an efficient oil, do not give signs of undue wear, even with a high superheat, up to $340^{\circ} \mathrm{C}$.

Except on one company, all engines for express service have four cylinders, with a large proportion of compounds; in a few cases,

* A description of the Schmidt superheater will be found in Mr. Flamme's Paper, "Superbeaters Applied to Locomotives on the Belgian State Railways" (Proceedings, I.Mech.E., 1905, page 409 and Plates 15, 16, 17). See also Mr. Fowler's Paper, "Superheating Steam in Locomotives" (Proceedings Inst. Civil Engineers, 1913-1914).

$\dagger$ In France the heating and superheating surfaces are generally computed on the side in contact with combustion gases, including the whole surface of the ribs in the case of Serve tubes. An exception on the Est Railway will be mentioned. All measures in the present Paper are metric, with the abbreviations adopted by the International Committee of Weights and Measures (Proceedings, I.Mech.E., 1900, page 394).

‡ This question has been mentioned in F. H. Trevithick and P. J. Cowan's Paper on "Some Effects of Superheating and Feed-water Heating on Locomotive Working" (Proceedings, I.Mech.E., 1913, Part 2, page 345), but treated from a different point of view. 
TABLE 1.

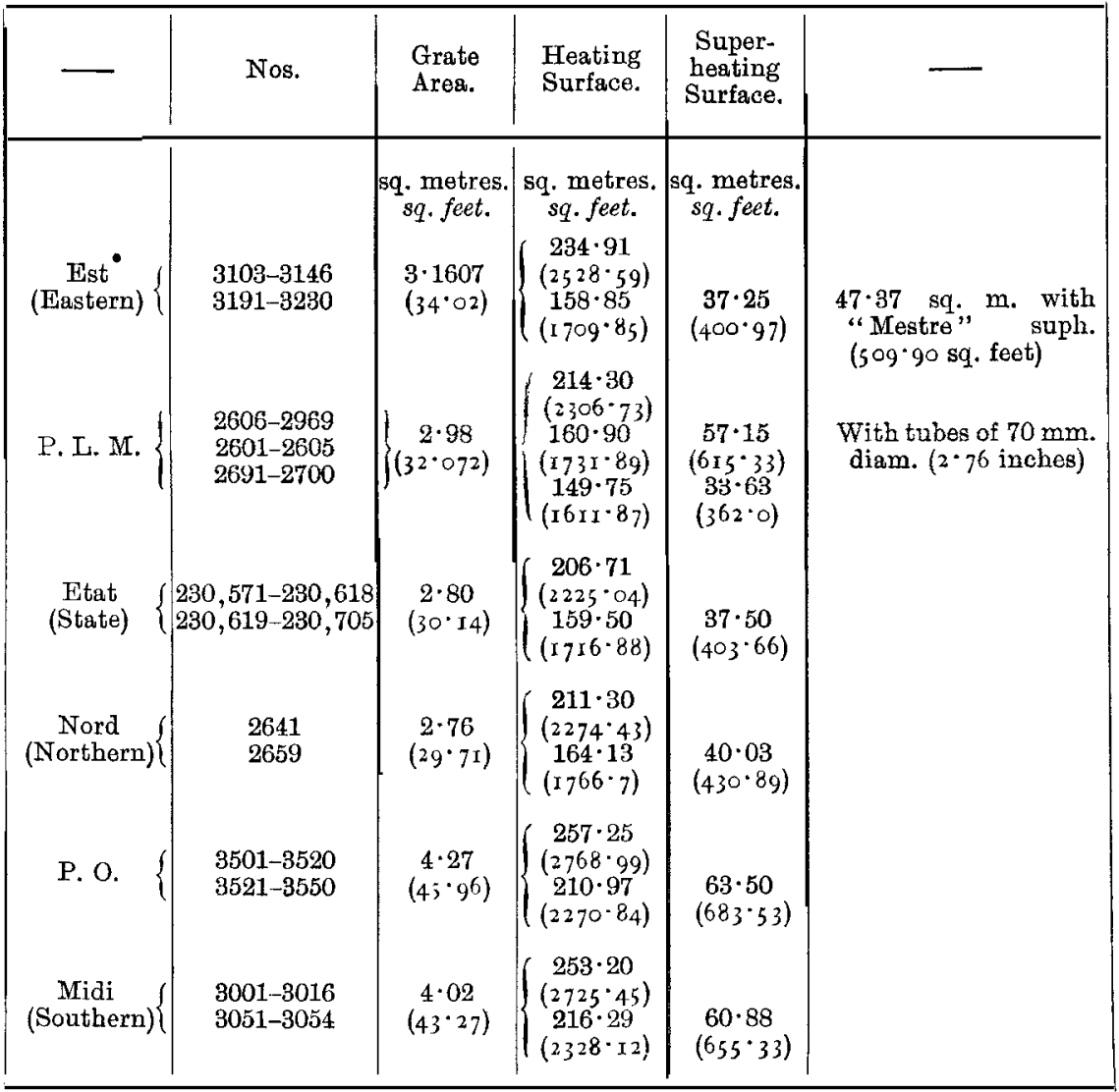

simple expansion, in four equal cylinders, is used, but the compound system appears altogether to be preferred. The one exception is the recent building, by the Midi Railway, of simple engines with only two cylinders, using superheated steam, for express service.*

When superheaters have been added to the four-cylinder compounds, the diameter of the high-pressure cylinders has been

* Simple engines on the same principle exist on other railways, but not for fast service. 
increased, the low-pressure cylinders being left unaltered. Piston valves are generally used on all cylinders, even on non-superheaters, but in a few cases, for instance, on Paris-Orléans engines, flat valves have been preserved on the low-pressure cylinders of superheaters.

The usual practice is to have four separate valve motions, of the Walschaert type, for the different cylinders of the compounds; the reversing gear can operate at will the high-pressure and the lowpressure motions together, or only one of them. The starting device, when admitting steam directly to the low-pressure cylinders, opens a direct exhaust to the high-pressure. An exception is to be found on the Paris-Lyon-Méditerranée engines: the low-pressure valve motion gives always the same admission (averaging 63 per 100) backwards and forwards; it is operated by the same screw as the high-pressure motion, but is only transferred from one position to the other when reversing. The high-pressure valve motion being designed to give a very prolonged admission (up to 88 per 100 ), the starting device comprises only a cock admitting live steam into the low-pressure cylinders, without special exhaust for the high-pressure.

As regards details it may be mentioned that, in some engines, the damper-box and doors, which enclose the collectors and ends of superheating pipes in the smoke-box, have been taken off; and no inconvenience seems to result from this suppression. Trouble would arise from a prolonged use of the blower, which may be avoided. If further experience proves that this mechanism can be dispensed with, including the steam cylinder for the automatic working of the damper, the saving in first cost and expenses for repairs will not be negligible, as well as the reduction in weight of about 300 kilograms (66olb.).*

The driver's station, which used to be on the right side of the engine, has been transferred to the left. Bogie wheels are, as a rule, braked.

* When the damper is shut the superheater elements lose their heat quickly, and take some time to regain it; this practically reduces the advantage of superheating for trains frequently stopping. For this reason the Midland Railway designed an apparatus to keep the doors open when the regulator is shut, provided the blower does not come into operation. 
TABLE 2.

Principal Dimensions of recent 4-6 Locomotives, with Superheaters.

\begin{tabular}{|c|c|c|c|c|c|}
\hline & \begin{tabular}{|c|} 
Est. \\
3191-3230 \\
4-cyl. \\
Compounds.
\end{tabular} & $\begin{array}{c}\text { P. L. M. } \\
2691-2700 \\
4 \text {-cyl. } \\
\text { Compounds. }\end{array}$ & $\begin{array}{c}\text { Etat. } \\
230,781- \\
230,800 . \\
\text { 4-cyl. } \\
\text { Simple. }\end{array}$ & $\begin{array}{c}\text { Nord. } \\
3538-3567 \\
3578-3597 \\
4-c y l . \\
\text { Compounds. }\end{array}$ & $\begin{array}{l}\text { Midi. } \\
\text { 3501-3516. } \\
\text { 2-cyl. } \\
\text { Simple. }\end{array}$ \\
\hline Grate area. . $\mathrm{m}^{2}$ & $3 \cdot 1607$ & $2 \cdot 98$ & $2 \cdot 78$ & 2 . & $2 \cdot 78$ \\
\hline Heating surface $\quad$ sq. $\mathrm{ft}^{2}$ & $\begin{array}{l}(34 \cdot 02) \\
158 \cdot 86\end{array}$ & $\begin{array}{l}(32 \cdot 07) \\
149 \cdot 75\end{array}$ & $\begin{array}{l}(29 \cdot 92) \\
136 \cdot 07\end{array}$ & $29^{\circ}$ & $(29 \cdot 92)$ \\
\hline sq. ft. & $\left(1700^{\circ} 90\right)$ & $(\mathrm{r} 6 \mathrm{II} \cdot 87)$ & $(1464 \cdot 65)$ & $\left(\begin{array}{c}104 \cdot 13 \\
(1766 \cdot 77)\end{array}\right.$ & $(1730 \cdot 27)$ \\
\hline $\begin{array}{r}\text { Superheating surface } \mathrm{m}^{2} \\
\mathrm{sg} . \mathrm{ft} .\end{array}$ & $\begin{array}{r}37 \cdot 25^{*} \\
(400 \cdot 97)\end{array}$ & $\begin{array}{l}33 \cdot 63 \\
(362 \cdot 0)\end{array}$ & $\begin{array}{l}43 \cdot 08 \\
(463 \cdot 18)\end{array}$ & $\begin{array}{c}40 \cdot 08 \\
(430.89)\end{array}$ & $\begin{array}{c}49 \cdot 32 \\
(530 \cdot 80)\end{array}$ \\
\hline mm. & 21 of 133 & 21 of 127 & 22 of 133 & 22 of 133 & 24 of 133 \\
\hline $\begin{array}{c}\text { Tubes, number and } \\
\text { outside dims. } \\
\text { mm. }\end{array}$ & $\begin{array}{c}(5 \cdot 23) \\
28 \text { of } 49 \\
(\mathrm{I} \cdot 93)\end{array}$ & $\begin{array}{c}(4 \cdot 99) \\
19 \text { of } 50 \\
(\mathbf{r} \cdot 97)\end{array}$ & $\begin{array}{c}\left(5^{-23}\right) \\
139 \text { of } 50 \\
(I \cdot 97)\end{array}$ & $\begin{array}{c}(5 \cdot 23) \\
20 \text { of } 50 \\
(1 \cdot 97)\end{array}$ & $\begin{array}{c}(5 \cdot 23) \\
143 \text { of } 50 \\
(1 \cdot 97)\end{array}$ \\
\hline sions $\cdot \underset{\text { mms. }}{\text { ins. }}$ & $\begin{array}{c}75 \text { of } 70 \dagger \\
(2 \cdot 76)\end{array}$ & $\begin{array}{c}64 \text { of } 70 \dagger \\
(2 \cdot 76)\end{array}$ & & $\begin{array}{c}60 \text { of } 70 \dagger \\
(2 \cdot 76)\end{array}$ & (2) \\
\hline Length between plates $\mathrm{m}$. & $4 \cdot 400$ & $4 \cdot 000$ & $4 \cdot 300$ & $4 \cdot 300$ & - \\
\hline $\begin{array}{r}\text { Mean diam. of barrel m. } \\
\text { ft. in. }\end{array}$ & $\begin{array}{l}1 \cdot 550 \\
(5-1)\end{array}$ & $\begin{array}{l}13-11 \\
1 \cdot 500 \\
(4-11)\end{array}$ & $\begin{array}{c}(14-1) \\
1 \cdot 600 \\
(5-3)\end{array}$ & $\begin{array}{l}(14-1) \\
1 \cdot 456 \\
(4-9)\end{array}$ & $\begin{array}{l}1 \cdot 533 \\
(5-0)\end{array}$ \\
\hline $\left.\begin{array}{l}\text { Height of axis } \\
\text { above rail }\end{array}\right\}$ ft. in. & $\begin{array}{l}2 \cdot 690 \\
(8-10)\end{array}$ & $\begin{array}{l}2 \cdot 600 \\
(8-6)\end{array}$ & $\begin{array}{c}2 \cdot 800 \\
(9-2)\end{array}$ & $\begin{array}{l}2 \cdot 630 \\
(8-7)\end{array}$ & - \\
\hline $\left.\begin{array}{c}\text { Effective } \\
\text { pressure }\end{array}\right\}$ lb. per sq. in. & $\begin{array}{c}16 \\
\left(227^{\circ} 6\right)\end{array}$ & $\begin{array}{c}16 \\
(227 \cdot 6)\end{array}$ & $\begin{array}{c}12 \\
\left(170^{\circ} 7\right)\end{array}$ & $\begin{array}{c}16 \\
\left(227^{\circ} 6\right)\end{array}$ & $\begin{array}{c}12 \\
\left(170^{\circ} \cdot 7\right.\end{array}$ \\
\hline $\left.\begin{array}{l}\text { Volume of water } \\
\text { in boiler }\end{array}\right\}$ cub. ft. & $\begin{array}{l}5 \cdot 770 \\
(203 \cdot 8)\end{array}$ & $\begin{array}{l}5 \cdot 420 \\
\left(\mathrm{r}^{\mathrm{I}} \cdot 4\right)\end{array}$ & $\begin{array}{c}6 \cdot 150 \\
(217 \cdot 2)\end{array}$ & $\begin{array}{c}4 \cdot 960 \\
(175 \cdot 16)\end{array}$ & $5 \cdot 440$ \\
\hline $\left.\begin{array}{l}\text { Volume of steam } \\
\text { in boiler }\end{array}\right\}$ cub. $\mathrm{ft}^{3}$ & $\begin{array}{l}2 \cdot 855 \\
(100 \cdot 81)\end{array}$ & $\begin{array}{l}2 \cdot 810 \\
\left(99^{\prime} 2\right)\end{array}$ & $\begin{array}{c}2 \cdot 850 \\
(100 \cdot 65)\end{array}$ & $\begin{array}{l}2 \cdot 720 \\
(96 \cdot 06)\end{array}$ & $2 \cdot 990$ \\
\hline $\left.\begin{array}{l}\text { Diameter of } \\
\text { coupled wheels } .\end{array}\right\}$ ft. in. & $\begin{array}{l}2 \cdot 090 \\
(6-10)\end{array}$ & $\begin{array}{c}2 \cdot 000 \\
(6-7)\end{array}$ & $\begin{array}{l}2 \cdot 040 \\
(6-8)\end{array}$ & $\begin{array}{c}1 \cdot 750 \\
(5-9)\end{array}$ & $\begin{array}{l}1 \cdot 750 \\
(5-9)\end{array}$ \\
\hline Diameter of & $\begin{array}{c}390 \\
\left(x-3^{*} 35\right)\end{array}$ & $\begin{array}{c}370 \\
(I-z+57)\end{array}$ & $\begin{array}{c}430 \\
(\mathbf{r}-4 \cdot 93)\end{array}$ & $\begin{array}{c}380 \\
(r-2 \cdot 96)\end{array}$ & $\begin{array}{c}590 \\
(I-I I \cdot 23)\end{array}$ \\
\hline$\cdot \underset{\text { ins. }}{\operatorname{mm} .}$ & $\begin{array}{c}590 \\
(I-x+93)\end{array}$ & $\begin{array}{c}540 \\
(1-9 \cdot 27)\end{array}$ & - & $\begin{array}{c}550 \\
(I-9 \cdot 66)\end{array}$ & - \\
\hline Stroke of pistons $\mathrm{mm}$. & $\begin{array}{l}680 \\
(2-3)\end{array}$ & $\begin{array}{c}650 \\
(2-2)\end{array}$ & $\begin{array}{c}640 \\
(2-1)\end{array}$ & $\begin{array}{c}640 \\
(2-1)\end{array}$ & $\begin{array}{c}640 \\
(2-1)\end{array}$ \\
\hline Weight, empty $\quad \begin{array}{l}\mathrm{kg} \\
\text { tons }\end{array}$ & $\begin{array}{l}71,580 \\
\left(70^{\circ} 7\right)\end{array}$ & $\begin{array}{l}67,440 \\
(6 \cdot 6 \cdot 4)\end{array}$ & $\begin{array}{l}65,500 \\
\left(64^{\circ} 4\right)\end{array}$ & $\begin{array}{l}64,045 \\
(63 \cdot 0)\end{array}$ & $\begin{array}{l}69,800 \\
(68 \cdot 7)\end{array}$ \\
\hline $\left.\begin{array}{l}\text { Weight in working } \\
\text { order }\end{array}\right\} \begin{array}{c}\mathrm{kg} . \\
\text { tons }\end{array}$ & $\begin{array}{l}77,950 \\
(76 \cdot 9)\end{array}$ & $\begin{array}{r}73,200 \\
\left(72^{\circ} 0\right)\end{array}$ & $\begin{array}{l}71,500 \\
\left(70^{\circ} 4\right)\end{array}$ & $\begin{array}{l}69,705 \\
(68 \cdot 6)\end{array}$ & $\begin{array}{l}76,300 \\
\left(75^{\circ} 1\right)\end{array}$ \\
\hline Weight adhesive . $\begin{array}{c}\mathrm{kg} . \\
\text { tons }\end{array}$ & $\begin{array}{l}53,110 \\
(52 \cdot 3)\end{array}$ & $\begin{array}{l}51,000 \\
\left(50^{\circ} \cdot 2\right)\end{array}$ & $\begin{array}{c}48,900 \\
(48 \cdot I)\end{array}$ & $\begin{array}{l}49,680 \\
\left(49^{\circ} \circ\right)\end{array}$ & $\begin{array}{l}54,000 \\
(53 \cdot r)\end{array}$ \\
\hline
\end{tabular}

* $45 \cdot 37 \mathrm{~m}^{2}(488 \cdot 4$ square feet) with Mestre's superheater.

+ Serve ribbed tubes. 
TABLE 3.

Prineipal Dimensions of recent Pacific Engines.

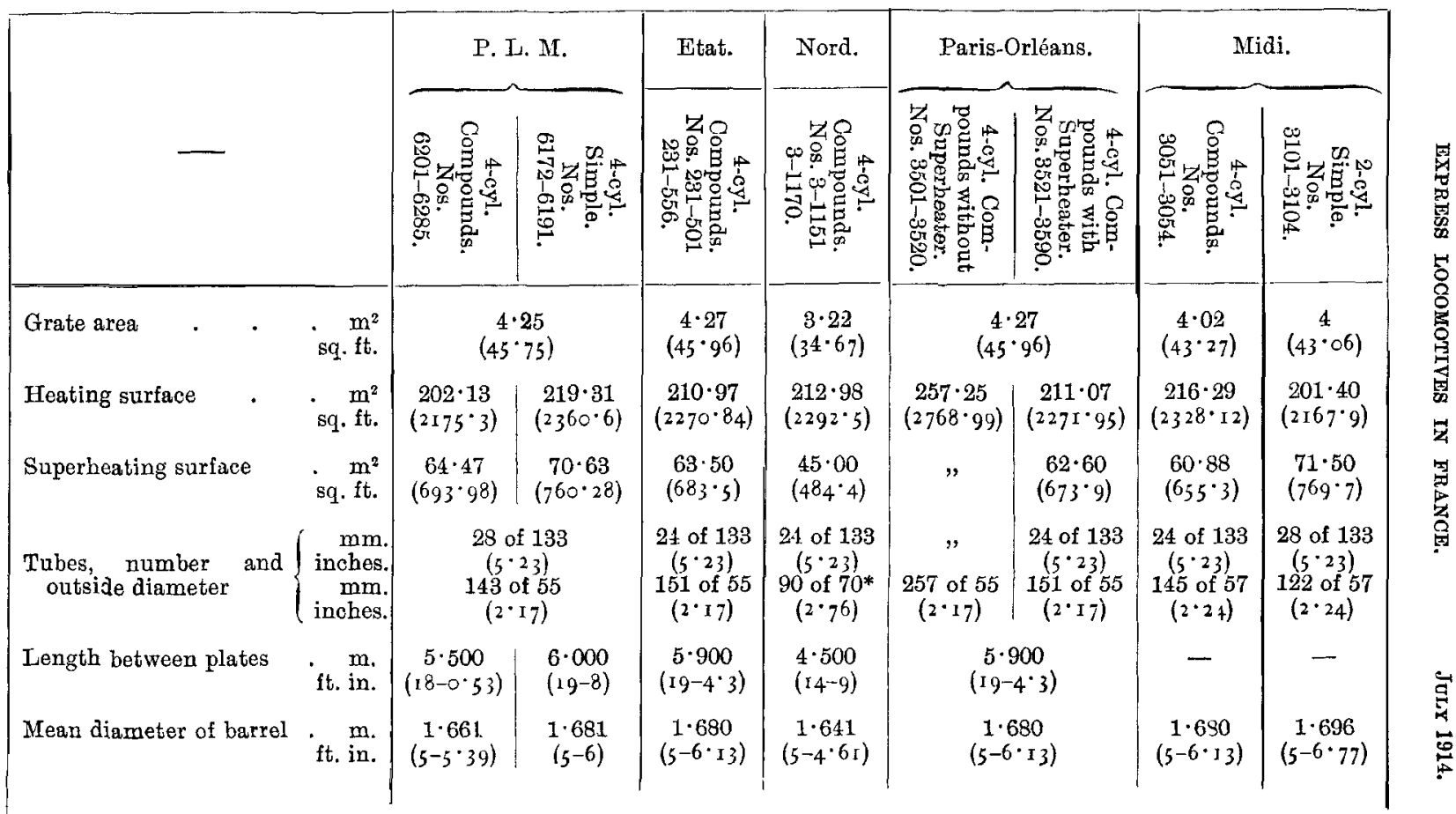




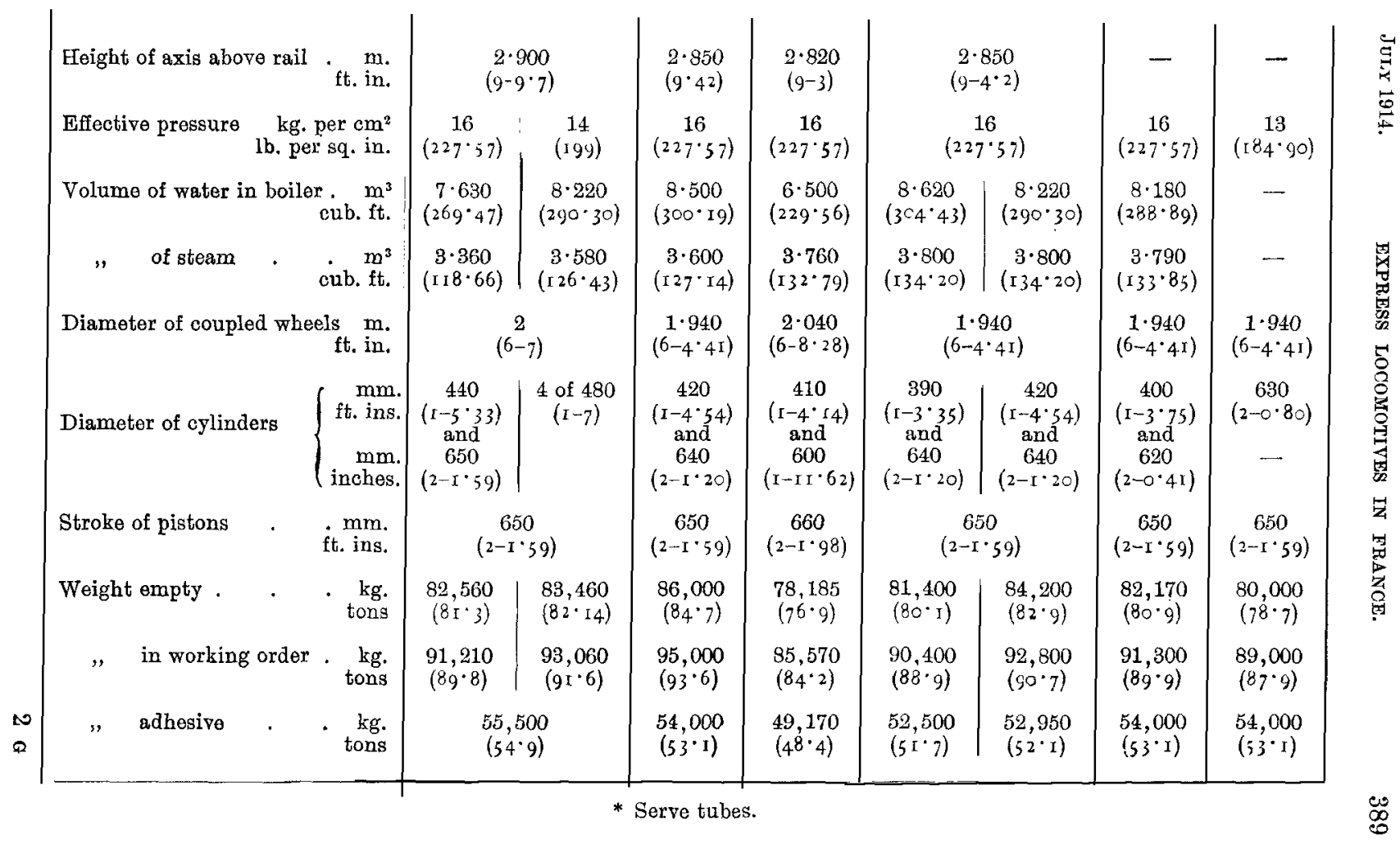


Two standard types of locomotives are used in France for express service, the ten-wheeler (4-6) and the Pacific. Tables 2 and 3 give the particulars of the latest types of these two sorts of engines for the different railway systems.

Details on the practice of each railway system will complete this general view.

Est.

130 six-coupled express locomotives $(4-6)$, four - cylinder compounds, with wheels of $2 \cdot 090$ metres (6 feet $10 \cdot 3$ inches) diameter, are in service on the Est system. The two first (Nos. 3101-3102), erected in 1903, have been described in the 1904 Paper on Compound Locomotives (page 362 and Fig. 10, Plate 53). They have been followed by :-

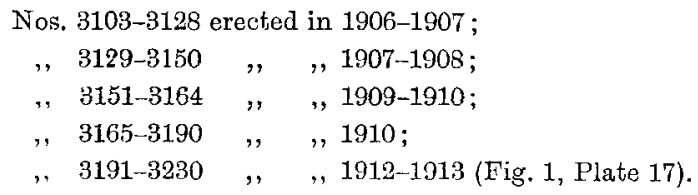

Nos. 3147 and following (84 engines) are fitted with superheaters.

To the flat valves of the first two engines (Nos. 3101-3i02), piston valves have been substituted in all others. The diameters of the cylinders, 350 millimetres ( $13^{\circ} 78$ inches) and 560 millimetres $(22.05$ inches $)$ with 660 millimetres $\left(25^{\circ} 9^{8}\right.$ inches) stroke in these two engines, have been enlarged to 360 millimetres ( $14 \cdot 17$ inches) and 590 millimetres $(23 \cdot 2$ inches); further, to 390 millimetres ( $15 \cdot 4$ inches) for the high-pressure cylinders of the superheating engines (Nos. 3147-3230). Might not the lowpressure cylinders be enlarged, too, with advantage? But these cylinders, with their diameter of 590 millimetres $\left(23^{\cdot} 2\right.$ inches), occupy the whole available space between the frames, and an increase of size would involve a radical change in the plan of the engine, which was not thought advisable. 
FIG. 2.-Squirrel-Cage Superheater (Mestre).

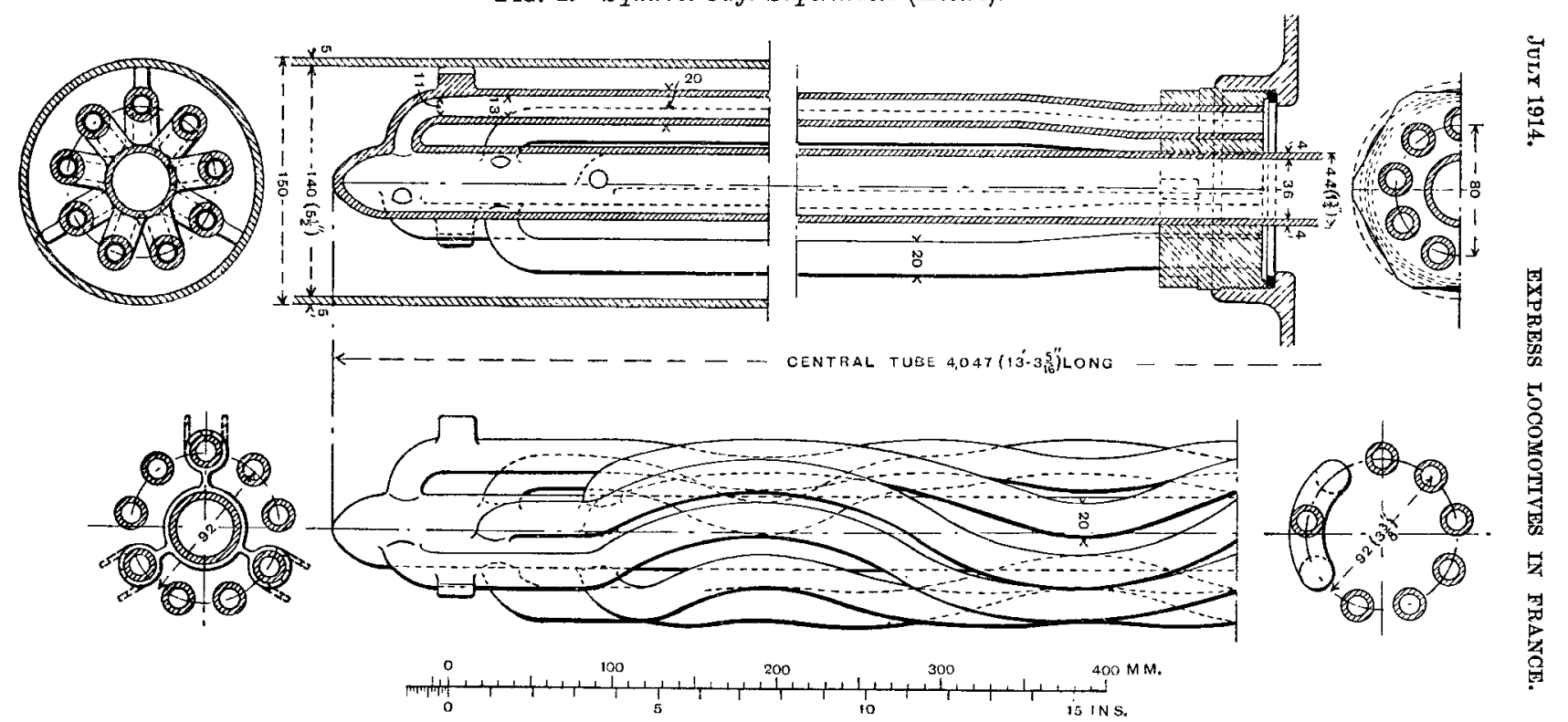

Total length of central tube 13 feet $3_{\frac{5}{16}}^{5}$ inches long $\times 1.42$ inch inside diameter $\times 0.16$ inch thickness.

10

$\Phi$

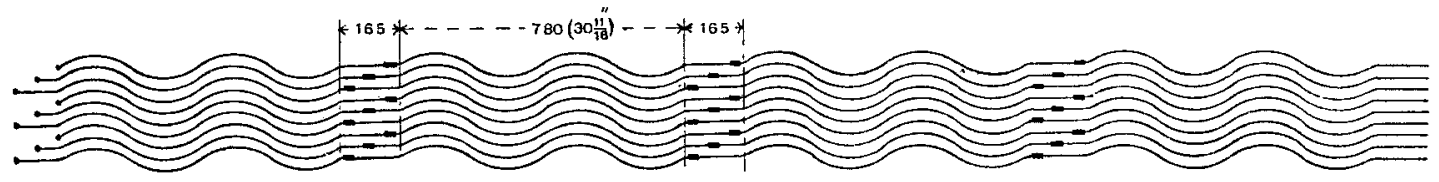

Sketch showing junctions in the 9 surrounding tubes. 
Engines 3103-3164 have two steam domes, but Nos. 3165 and following, only one.

Other systems of superheaters besides the Schmidt have been experimented upon. First, for fear of orerheating the highpressure cylinders, superheating in two stages was resorted to: high pressure steam being moderately superheated, receiver steam passed a second superheater. This plan has been abandoned. A "helical superheater," on the principle of the Field tube, with ribs, was fitted to some engines, and was abandoned, too, on account of its insufficient surface and of the difficulty of cleaning its outside ribs. Another system is the Mestre "squirrel-cage superheater," Fig. 2, which is working on some engines and gives ample surface.

It may be mentioned that in engines Nos. 3129-3146 the receiver comprises a number of large pipes in the smoke-box, with a heating surface of $7 \cdot 736$ square metres $(83 \cdot 3$ square feet); the object being to dry or even to superheat the low-pressure steam. This contrivance does not seem to have any well-marked effect.

The ends of the superheating tubes, which are steel castings in Schmidt's system, come close to the fire-box, the distance being reduced to 550 millimetres $(2 \mathrm{I} \cdot 7$ inches). It has been found that these castings are rapidly covered with a slag deposit that protects them from a too intense heat.

With the exception of the points mentioned, the several lots of these engines show but slight differences. The principal dimensions are given in Table 2. The heating surface is computed on the side in contact with combustion gases; in the case of Serve tubes, it is reckoned as the mean between the actual surface ribs included, and the surface of a plain tube of same inside diameter. The surface of the superheaters is the mean between their inside and outside surfaces.

As usual, the cylinders are provided with air relief-valves, which open automatically when steam is shut off; they are quite necessary with piston-valves, unless Schmidt's by-pass be used. Some trouble having been experienced in the working of these valves, which must be large, they have been replaced by groups of six small ones, Fig. 3 . 
All wheels, bogie included, are fitted/with brake blocks. These engines have six-wheeled tenders, holding 22 cubic metres $\left(4,85^{\circ}\right.$ gal.) of water and 8 tons of coal, weighing empty 20 tons.

Mr. Lancrenon, Chief Engineer of the Est Railway, declares these six-coupled engines give entire satisfaction. Although utilized mainly for fast trains, they can negotiate all passenger, and even

Fig. 3.-Sextuple Air Relief-Valve (Est).

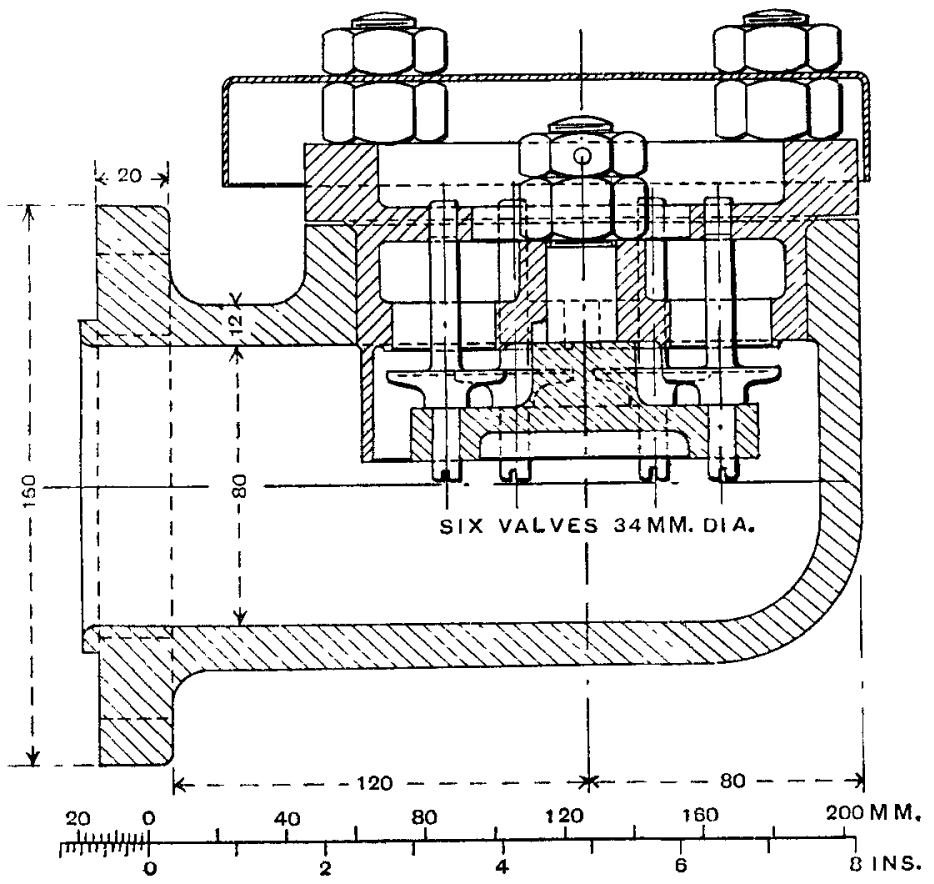

occasionally heavy goods trains. They attain easily the limit speed of 120 kilometres $(74.6$ miles) an hour, run smoothly without injuring the track ; the expenses for upkeep, as well as for coal- and water-consumption, are moderate.

In addition to these express engines, the Est Railway's stock comprises 212 locomotives of a similar type, with wheels of $1 \cdot 750$ metre ( 5 feet 8.9 inches), which may occasionally haul express trains. These engines have been mentioned in the previous Papers 
on locomotives.* The Atlantic engines of the same company, described in the 1904. Paper (Fig. 8, Plate 52), number only two, ordered for sake of comparison with the 4-6 engines.

As regards boiler pressure, the practice of the Est Railway is to reduce the maximum allowed by one unit, so as to be certain that this maximum is never exceeded. On boilers marked 16 kilograms per square centimetre $(227.6 \mathrm{lb}$. per square inch), the safety-valves blow off at 15 kilograms per square centimetre $(213.35 \mathrm{lb}$. per square inch).

\section{Paris-Lyon-Méditerranée.}

Since 1904 the Paris-Lyon-Méditerranée Railway ordered: 160 six-coupled bogie engines (4-6), from 1905 to 1909 ; 20 Atlantics in 1906 ;

177 Pacifies from 1909 to 1912.

All with 2 metres ( 6 feet 6.74 inches) driving wheels.

To these may be added 170 ten-wheelers, with 1.80 metres ( 5 feet 10.9 inches) wheels, ordered in 1910 , and utilized on certain lines for express trains.

Of these 527 locomotives 198 have superheaters; all have four cylinders, and are compounds, with the exception of 91 engines, using superheated steam in four equal cylinders, on the simple expansion principle.

The 4-6 and the Atlantic locomotives were designed in 1904, with the same boilers and cylinders. Owing to the very good results obtained from the six-coupled, which have the advantage of a greater adhesive weight over the Atlantics, the building of engines of this latter class has been discontinued.

Of these 160 ten-wheelers (Nos. 2601-2760), 10 (Nos. 26912700) have been built with an ordinary Schmidt superheater; 5 engines (Nos. 2601-2605), built in 1905, received later on a special Schmidt superheater with small tubes and two collectors;

* Proceedings, I.Mech.E., 1900, Fig. 12, Plate 46; and 1904, Fig. 3, Plate 50, and Fig. 9, Plate 52. 


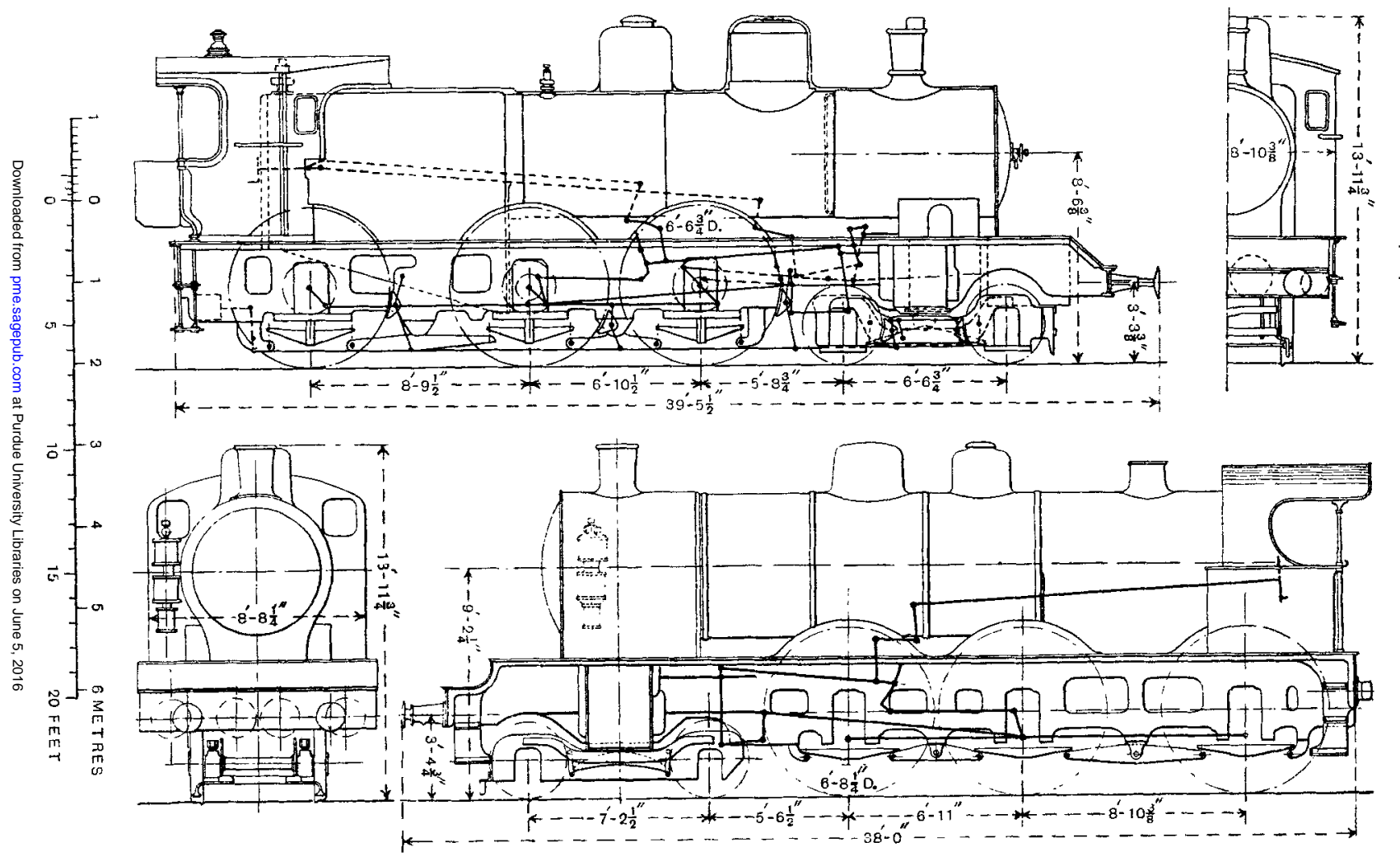

FIG. 4.

Nos.

2601-2605

2691-2700

Paris-Lyon-

Mediterranée.

230,781 -

230,800 .

Etat.

4-cyl. Simple

Expansion. 
these engines having Serve tubes of 70 millimetres $\left(2 \cdot 7^{6}\right.$ inches $)$ outside diameter, the superheating tubes found room in tubes of the same diameter without ribs.

In Nos. 2691-2700 (Fig. 4), built with superheaters, the diameter of the high-pressure cylinders has been increased from 340 millimetres ( 13.39 inches) to 370 millimetres ( 14.57 inches), the low-pressure cylinders remaining the same (540 millimetres) (21.27 inches). Of the five engines, fitted later on with superheaters, three only had their high-pressure cylinders increased, in view of comparative experiments. Table 2 gives the principal dimensions of these engines.

A more powerful engine being wanted, a Pacific was designed in 1908 , and 177 were put in service, in different lots, showing some differences. The main question to be resolved was whether, with superheated steam, simple expansion and a moderate boiler pressure were not as advantageous as the compound system with a higher pressure.

The first two Pacifics, delivered in 1909, were a four-cylinder compound (No.6001), to which a Schmidt superheater was added in 1913, and a four-cylinder simple (No.6101), with superheater and pressure reduced to 12 kilograms per square centimetre $\left(170^{\circ} 7 \mathrm{lb}\right.$. per square inch); afterwards 70 similar simple engines (Nos. $6102-$ 6171 ) were ordered; but it must not be inferred that the question of simple expansion versus compound was definitely settled, as the orders in 1912 comprised 85 four-cylinder compounds, Fig. 5, Plate 17, with superheaters (Nos. 6201-6285), and 20 four-cylinder simple engines (Nos. 6172-6191). In these last engines, the boiler pressure was increased from 12 to 14 kilograms per square centimetre $\left(170^{\circ} 7\right.$ to $199^{\circ} \mathrm{I} \mathrm{lb}$. per square inch), as it was noticed that in the first engines the drop of pressure from boiler to steam chest amounted frequently to 3 kilograms per square centimetre $(42 \cdot 67 \mathrm{lb}$. per square inch), owing to the presence of the superheater.

All Pacifics have plain tubes, without ribs, with an outside diameter of 55 millimetres $(2 \cdot 17$ inches), in relation to their great length, 5.50 metres ( 18 feet 0.5 inch) and 6 metres ( 19 feet 8.22 inches). The principal dimensions of these Pacifics will be found in Table 3 (pages 388-9). 
A tender holding 28 cubic metres $(6,180$ gal. $)$ of water and 5 tons of coal, carried on two bogies, has been designed for the Pacifics. It weighs, empty, 28 tons.

Comparative trials of No. 6102 (simple) and No. 6204 (compound) took place between Laroche and Dijon, the line rising from Laroche to Blaisy (distance 132 kilometres) $(82.0$ miles) with long continuous grades of about 5 millimetres per metre ( $\mathrm{I}$ in 200 ).

With trains weighing as much as 487 tons, locomotive 6102 (simple) indicated 2,051 h.p.* (2,022 b.h.p.), the utilized power on the draw-bar being 1,364 h.p. (I,342 b.h.p.). The water consumed per hour and indicated horse-power varied, in the different experiments, from 8.67 kilograms $(19 \cdot 1 \mathrm{lb}$ ) to 9.77 kilograms $(2 \mathrm{r} \cdot 5 \mathrm{lb}$.), the gross coal-consumption, including lighting up of fires, from 1.55 kilogram $\left(3.4^{2} \mathrm{lb}\right.$.) to 1.81 kilogram $(4.0 \mathrm{lb}$.), and the net coalconsumption (deduction made for lighting up) from $1 \cdot 35$ kilogram $(2.98 \mathrm{lb}$.) to 1.59 kilogram $(3.5 \mathrm{lb}$.). In some cases as much as 700 kilograms $(1,543 \mathrm{lb}$.) of coal were shovelled in per hour and square metre (10.764 square feet) of grate.

Compound locomotive 6,204 hauled trains of 646 tons at an average speed of 80 kilometres $\left(49 \cdot 7\right.$ miles) to 90 kilometres $\left(55^{\circ} \cdot 9\right.$ miles) an hour from Laroche to Blaisy; 2,425 h.p. (2,39 r b.h.p.) was indicated and 1,604 h.p. ( 1,582 b.h.p.) registered by the dynamometer on the draw-bar. The water consumed per hour and indicated horse-power varied from 6.13 kilograms $(13.5 \mathrm{llb}$.) to 6.82 kilograms $(15.03 \mathrm{lb}$ ), the gross coal-consumption from 1.03 kilogram $(2 \cdot 27 \mathrm{lb}$.) to 1.22 kilogram $(2.69 \mathrm{lb}$ ), and the net coalconsumption from 0.933 kilogram $(2.06 \mathrm{lb}$.) to 1.08 kilogram $(2 \cdot 38 \mathrm{lb}$.$) . The rate of combustion never exceeded 537$ kilograms $(1,183.9 \mathrm{lb}$.) per hour and square metre $(10.764$ square feet) of grate.

Mr. Maréchal, Chief Engineer of the Paris-Lyon-Méditerranée Railway, concludes: "The experiments show the compound locomotives at the same time more powerful and more economical than the simple. Consequently we discontinued the building of simple engines."

* 1 French $h . p$. equals 75 kilogrammetres $\left(54^{2} 5\right.$ foot-lb.) per second. 
The 170 4-6 engines (Nos. 2430-2599) have the same general lines as the 2601-2760, but with smaller wheels, 1.800 metre ( 5 feet 10.87 inches) instead of 2 metres ( 6 feet 6.74 inches), boilers a little more powerful (grate area, $3 \cdot 08$ square metres $\left(33^{\circ} 2\right.$ square feet) against $2 \cdot 98$ square metres $(32 \cdot \mathrm{x}$ square feet)), heating surface, $239 \cdot 64$ square metres $(2,579 \cdot 5$ square feet) against $214 \cdot 30$ square metres $(2,306 \cdot 7$ square feet)), cylinders of 370 millimetres (14.57 inches) and 590 millimetres $(23.23$ inches) against 340 millimetres ( $13 \cdot 39$ inches) and 540 millimetres (21 27 inches)) with same stroke of 650 millimetres $\left(25^{\circ} 59\right.$ inches). The object was to have a powerful engine to haul express trains on difficult sections, where the permanent way could not allow the running of Pacifics. It will be noticed that these engines have no superheaters.

\section{ETat.}

The express engines ordered by the State Railways (formerly Ouest) since 1904, include 10 Atlantics, built in 1905, 273 4-6 engines and 108 Pacifics.

The Atlantics are four-cylinder compounds with cylinders of 360 millimetres ( $14^{\cdot} \mathrm{I} 7$ inches) and $600(23 \cdot 62$ inches $) \times 640$ millimetres $(25 \cdot 20$ inches), wheels of $2 \cdot 040$ metres ( 6 feet $8 \cdot 3 \mathrm{I}$ inches), grate area $3 \cdot 10$ square metres $(33 \cdot 4$ square feet), and heating surface $239 \cdot 40$ square metres $(2,576 \cdot 9$ square feet).

Of the 4-6 engines, 108 (Nos. 230,511-230,618), built from 1904 to 1908, are similar to Nos. 2701-2720, described in the 1904 Paper on Compound Locomotives (page 355 and Fig. 2, Pl. 50), with unimportant differences; 87 (Nos. 230,619-230,705), built in 1908 and 1912 , have a larger grate area $\left(2 \cdot 80\right.$ square metres ( $30^{\circ} 14$ square feet)), and Schmidt superbeaters, the diameter of the high-pressure cylinders being enlarged to 380 millimetres (14.96 inches). The heating surface is $158 \cdot 50$ square metres $(I, 706 \cdot I$ square feet), and the superheating surface $37 \cdot 50$ square metres ( $403 \cdot 7$ square feet).

Another lot comprises 58 engines (Nos. 230,801-230,858), built from 1908 to 1912 , on about the same lines, but with smaller 
wheels ( 1.850 metre (6 feet 0.83 inch) instead of 1.940 metre ( 6 feet $4 \cdot 3^{8}$ inches)), a somewhat larger boiler and bigger cylinders

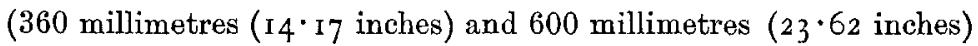
$\times 640$ millimetres $\left(25^{\circ} 20\right.$ inches $)$ ), without superheat.

Nos. 230,781-230,800 with superheaters, Fig. 6 (page 395) are simple expansion engines, with four equal cylinders, 430 millimetres ( 6.93 inches) $\times 640$ millimetres $\left(25^{\circ} 20\right.$ inches). The principal dimensions are given in Table 1 (page 385).

Of the Pacifies, two (Nos. 231,001-231,002), built in 1908, are four-cylinder compounds without superheaters, with wheels of 1.940 metre ( 6 feet $4^{\cdot} 3^{8}$ inches). The 50 following ones (Nos. 231,011-231,060), equally four-cylinder compounds without superheaters, Fig. 7, Plate 18, have smaller wheels, 1.850 metre ( 6 feet 0.83 inch) and date from 1910. The 56, Nos. 231,501-231,556, four cylinder compounds with superheat, are not yet in service. The wheel diameter of 1.940 metre ( 6 feet $4^{\cdot 38}$ inches) has been reverted to. Piston-valves are used on the high-pressure cylinders and flat valves on the low-pressure. The same shape of grate as on the Paris-Orléans, Fig. 13 (page 409), is used, narrow in front, wider in the back part, but with a half cylindrical outer shell, flush with the barrel, instead of the flat Belpaire top. The principal dimensions are given in Table 3 (pages 388-9).

No precise experimental data, referring to the types of engines mentioned, are available. As regards the comparison of simple four-cylinder engines versus compounds, all with superheaters, the impression of some officials of the State Railways seems to be in favour of the compound principle.

Troughs for picking up water have been established close to Arnières, 115 kilometres ( 7 I 5 miles) from Paris on the Caen line, and 121 tenders are fitted with scoops; 56 more are in preparation.

\section{Nord.}

The locomotives used for fast trains on the Nord since 1904, all four-cylinder compounds, are :- 
35 Atlantics, the last 15 of which (Nos. 2661-2675) were built in 1904-1905; $1504-6$ engines (Nos. 3513-3662), erected from 1909 to 1912 ; 2 "Baltic" engines (4-6-4), Nos. 3,1101-3,1102, built in 1911; 20 Pacifics (Nos. 3, 1151-3, 1170), built in 1912.

Of the Atlantics, 20 were in service before 1904 and have been described in the Proceedings, I.Mech.E. (1900, page 400 and Fig. 11, Pl. 46; 1904, page 334 and Fig. 1, Pl. 50). To the new ones superheaters have been added; the heating surface, $211 \cdot 30$ square

FIG. 8.-Walschaert Gear for Piston Valves with central admissioni(Nord).

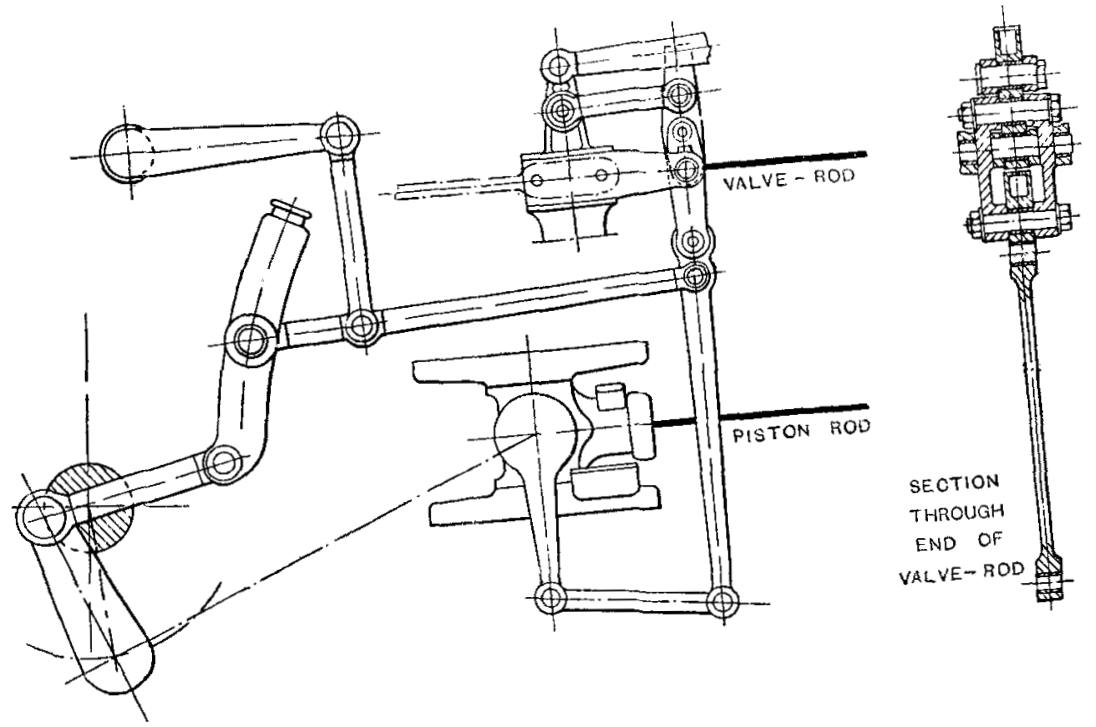

metres $(2,274 \cdot 4$ square feet) was reduced to $164 \cdot 13$ square metres $(\mathrm{r}, 766.7$ square feet), with a superheating surface of 40.03 square metres ( 430.9 square feet); the high-pressure cylinders have been enlarged from 340 millimetres ( 3.39 inches) to 390 millimetres ( 15.35 inches), the low-pressure remaining at 560 millimetres (22.05 inches); piston-valves have been substituted for flat valves. Steam is admitted in the centre of the piston-valves of the highpressure cylinders, and the valve-rods are at a greater distance from the piston-rods than with the flat valves, For these reasons 
the motion derived from the Walschaert gear is transmitted to the valve-rod by a combination of levers, Fig. 8 , which may appear somewhat complicated, the motive being the desire to change as little as possible the design of the old engine.

By a modification of the compensating beams, the adhesive weight has been increased from 33 tons to the new limit of 36 .

The results in Table 4 prove the advantage of superheating.

With the normal weight of 250 tons for this train, the

TABLE 4.

\begin{tabular}{|c|c|c|}
\hline-1 & $\begin{array}{l}\text { Atlantic No. 2641 } \\
\text { (Saturated Steam). }\end{array}$ & $\begin{array}{c}\text { Atlantic No. 2659 } \\
\text { (Superheated Steam). }\end{array}$ \\
\hline No, and date of train & 179,22 August 1900 & 179, 19 April 1913 \\
\hline Weight of train & 322 tons & 356 tons \\
\hline Average speed on level . & $\begin{array}{l}107 \mathrm{~km} \text {. an hour } \\
(66.5 \text { miles })\end{array}$ & $\begin{array}{l}113 \mathrm{~km} \text {. an hour } \\
\left(70^{\circ} \text {. I miles }\right)\end{array}$ \\
\hline $\begin{array}{l}\text { Average speed on } 5 \mathrm{~mm} \text {. per } \\
\mathrm{m} .(\mathrm{I} \text { in } 200) \text { incline }\end{array}$ & $\begin{array}{l}90 \mathrm{~km} \text {. an hour } \\
\left(55^{\circ} \cdot 9 \text { miles }\right)\end{array}$ & $\begin{array}{l}93 \mathrm{~km} \text {. an hour } \\
\left(57^{\circ} 8 \text { miles }\right)\end{array}$ \\
\hline 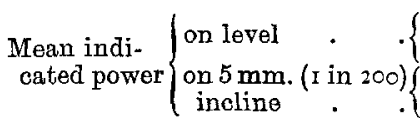 & $\begin{array}{l}1235 \text { h.p. } \\
\left.\text { (1 } 2177^{\circ} \text { h.p. }\right) \\
1295 \text { h.p. } \\
\left(1276^{\circ} 9 \text { b.p. }\right)\end{array}$ & $\begin{array}{l}1435 \text { h.p. (I } 4{ }^{\circ} 9 \text { h.p.) } \\
\text { (increase 16,2 p. 100) } \\
1510 \text { h.p. (I } 488^{\circ} \cdot \text { h.p.) } \\
\text { (increase 16,6 p. 100) }\end{array}$ \\
\hline $\begin{array}{l}\text { Water con- } \\
\text { sumed }\end{array}\left\{\begin{array}{l}\text { per } \mathrm{km} .\left(0^{\circ} 62 \mathrm{r} \text { mile }\right) \\
\text { per ton-km. }\end{array}\right\}$ & Not measured & $\left\{\begin{array}{l}91.51 .\left(20^{\circ} 13 \text { gals. }\right) \\
0.257 \text { 1. }(0.057 \text { gal. })\end{array}\right\}$ \\
\hline $\begin{array}{l}\text { Coal con- } \\
\text { sumed }\end{array}\left\{\begin{array}{l}\text { per } \mathrm{km} \cdot(0 \cdot 62 \mathrm{r} \text { mile }) \\
\text { per ton-km. }\end{array}\right\}$ & Not measured & $\left(\begin{array}{c}16 \mathrm{~kg} \cdot(35 \cdot 27 \mathrm{lb} .) \\
0 \cdot 0449 \mathrm{~kg} \cdot(0 \cdot 099 \mathrm{lb} .)\end{array}\right)$ \\
\hline $\begin{array}{l}\text { Duration of run, Paris-St. } \\
\text { Quentin }(153 \mathrm{~km} .)\left(95^{\circ} \text { I miles }\right)\end{array}$ & $1 \mathrm{br} .35 \mathrm{~min} .45 \mathrm{sec}$. & $1 \mathrm{hr} .35 \mathrm{~min}$. \\
\hline
\end{tabular}

consumption per kilometre was $11 \cdot 9$ kilograms $(26 \cdot 24 \mathrm{lb}$.) of coal and 83 litres ( 18.26 gallons) of water $(0.0476$ kilogram $(0.105 \mathrm{lb})$. of coal per ton-kilometre), with superheat, against $13 \cdot 7$ kilograms $\left(30^{\circ} 20 \mathrm{lb}.\right)$ and 109 litres $\left(23^{\circ} 9^{8}\right.$ gallons $)$ without $(0.0548$ kilogram $(0.12 \mathrm{ll}$.) $)$ per ton-kilometre). Thus the new engine shows an economy of $13 \cdot 1$ per 100 on coal, and 23.85 per 100 on water.

The 4-6 engines, with 1.750 metre ( 5 feet 8.8 inches) wheels, Fig. 9, have been designed for express trains, weighing 350 tons 
FIG. 9.- Nos, 2588-3567, 3578-3597. Nord.

:

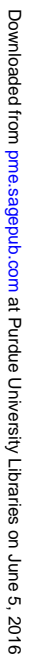

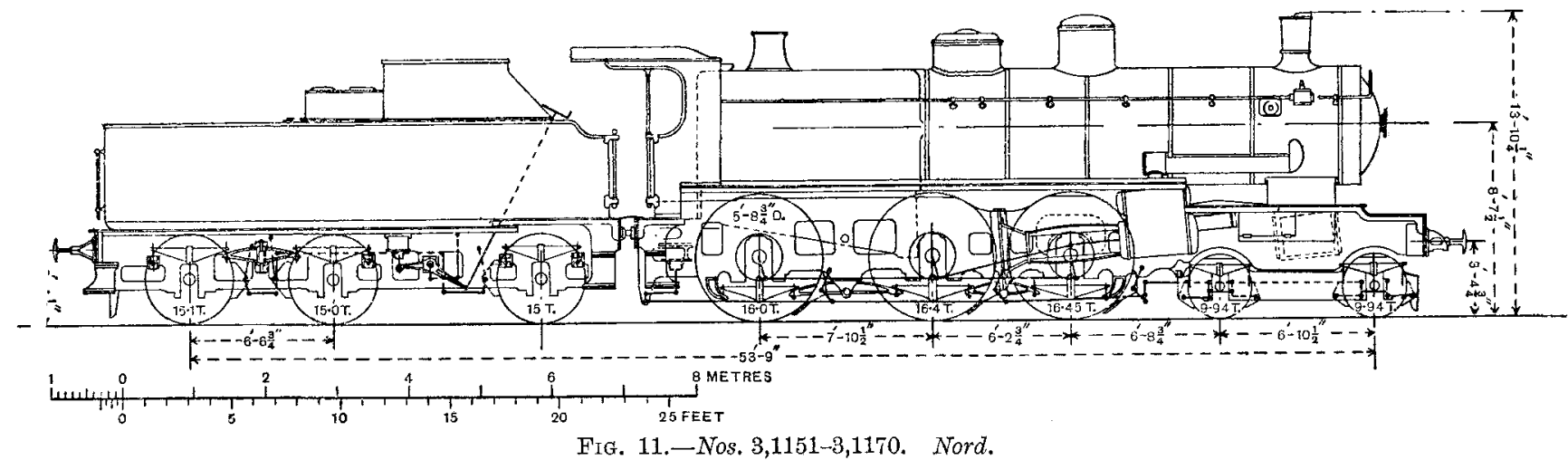

FIG. 11.-Nos. 3,1151-3,1170. Nord.
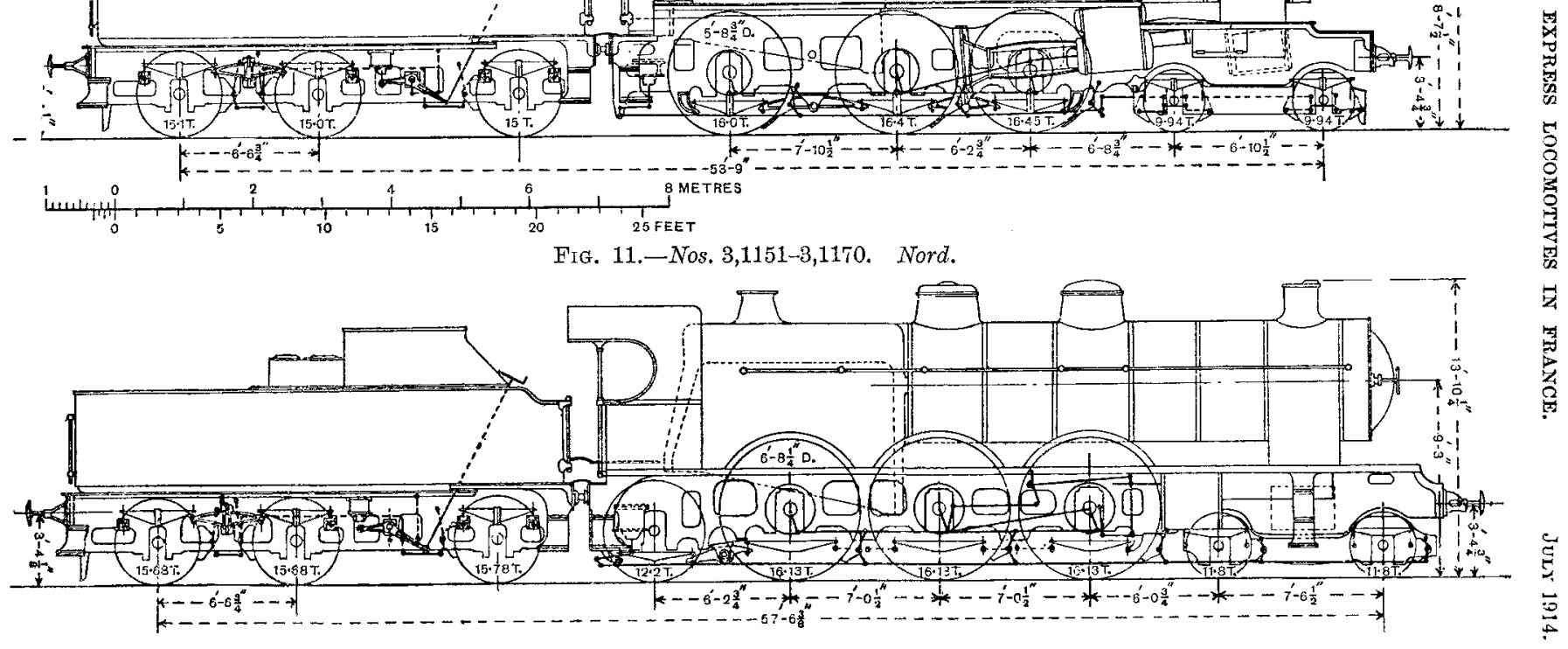
and more, with frequent stoppages. They have the boilers of the Atlantics, and the frames and motions of former 4-6 engines, Nos. 3078-3354.* The small diameter of wheels resulted from the necessity to keep down their weight, as a compensation for the increase due to the boiler; narrow limits per axle and per metre of length were not to be exceeded; at that time some bridges on the main lines, not yet renewed, could not allow heavier engines. Experience has proved that, even with that diameter of $1 \cdot 750$ metre ( 5 feet 8.8 inches), provided the cylinder ports were large enough, speeds of 110 kilometres $(68 \cdot 4$ miles) to 115 kilometres (71.5 miles) an hour were quite easy. These engines take frequently the place of Atlantics even with the faster trains, the only practical difference being a difficulty to attain a speed of 120 kilometres (74.6 miles) an hour.

The 57 first engines have cylinders of 350 millimetres $\left(13 \cdot 7^{8}\right.$ inches) and 550 millimetres (2I.66 inches) by 640 millimetres $\left(25^{\cdot} 20\right.$ inches) as the old Nos. 3078-3354, but the ports are 30 and 24 per 100 larger, being 35 millimetres (I.38 inches) by 350 millimetres ( $\mathrm{I}_{3} \cdot 7^{8}$ inches), instead of 35 millimetres ( $1 \cdot 38$ inch) by 270 millimetres on the high-pressure cylinders, and 40 millimetres $(x \cdot 58$ inches) by 520 millimetres $(20.48$ inches), instead of 40 millimetres (I.58 inch) by 420 millimetres (i $5 \cdot 54$ inches) on the low-pressure cylinders. $\dagger$ Balanced flat valves are used. The wheels have no splashers, the running board extending above; a transverse foot-plate, as low as possible, behind the crank axle, facilitates the visit and lubrication of the inside motion. A door is provided in front of the cab, on the right-hand side.

The 25 first engines use saturated steam; the 125 following (Nos. 3538-3662), erected since 1911, have Schmidt superheaters; their high-pressure cylinders have been enlarged from 350 millimetres $(13.78$ inches) to 380 millimetres ( 14.96 inches), and fitted with piston-valves of 200 millimetres $(7 \cdot 87$ inches $)$ diameter, the valve motion being altered as on Fig. 8 (page 400).

* Proceedings, I.Mech.E., 1900, page 404, and Fig. 13, Plate 47.

$\dagger$ In his Paper on "Compounding and Superheating in Horwich Locomotives" Mr. George Hughes advocates large ports (Proceedings, I.Mech.E., 1910, page 423). 
The principal dimensions of these engines will be found in Table 2 (page 387 ).

The six-wheeled tenders of some of these engines have been designed with a view of reducing, as far as possible, the fireman's work. As seen on Fig. 9, the coal tank is entirely in front, with a

TABLE 5.

\begin{tabular}{|c|c|c|c|c|c|}
\hline Nos. of Engine & 3,541 & \multicolumn{2}{|c|}{3,538} & \multicolumn{2}{|c|}{3,624} \\
\hline $\begin{array}{l}\text { No. and date of train } \\
\text { Weight of train . tons }\end{array}$ & $\begin{array}{l}115 \\
\text { 4 July } \\
1912 \\
312\end{array}$ & $\begin{array}{c}109 \\
14 \text { Dec. } \\
1912 \\
289\end{array}$ & $\begin{array}{l}122 \\
14 \text { Dec. } \\
1912 \\
346\end{array}$ & $\begin{array}{c}\mathrm{Y} \mathrm{B} \\
4 \mathrm{Feb} . \\
1913 \\
733\end{array}$ & $\begin{array}{l}\text { X A } \\
7 \mathrm{Feb} . \\
1913 \\
1020\end{array}$ \\
\hline$\underset{\text { on level }}{\text { Average speed }}\} \mathbf{k m}$. per $\mathrm{h}$ & $\begin{array}{c}110 \\
(68 \cdot 4)\end{array}$ & $\begin{array}{c}110 \\
(68 \cdot 4)\end{array}$ & $\begin{array}{c}100 \\
(62 \cdot I)\end{array}$ & $\begin{array}{c}50 \\
(3 I \cdot I)\end{array}$ & $\begin{array}{c}45 \\
\left(28^{\circ} \cdot 0\right)\end{array}$ \\
\hline $\begin{array}{l}\text { Average speed } \\
\text { on } 5 \text { mm. } \\
\left.\begin{array}{l}\text { (I in 200) } \\
\text { incline }\end{array}\right\} \mathrm{km} \text {. per } \mathrm{h} \text { miles }\end{array}$ & $\begin{array}{c}90 \\
\left(55^{\circ} 9\right)\end{array}$ & $\begin{array}{c}90 \\
\left(55^{\circ} 9\right)\end{array}$ & $\begin{array}{c}80 \\
\left(49^{\circ} 7\right)\end{array}$ & $\begin{array}{c}35 \\
(2 I \cdot 75)\end{array}$ & $\begin{array}{c}25 \\
\left(15^{\circ} 3\right)\end{array}$ \\
\hline $\left.\begin{array}{l}\text { Average speed } \\
\text { on } 8 \text { mm. } \\
\begin{array}{l}\text { (I in } \\
\text { incline }\end{array}\end{array}\right\} \mathrm{km}$. per h. & $"$ & ", & ", & $\left(\begin{array}{c}30 \\
(13 \cdot 6)\end{array}\right.$ & " \\
\hline $\begin{array}{l}\text { Water con- } \\
\text { sumed }\end{array}\left\{\begin{array}{c}\text { per km. } 1 . \\
\text { per t-km. } 1 .\end{array}\right.$ & $\begin{array}{l}\text { No } \\
\text { moasure- } \\
\text { ment }\end{array}$ & $\begin{array}{l}\text { No } \\
\text { measure- } \\
\text { ment }\end{array}$ & $\begin{array}{l}\text { No } \\
\text { measure- } \\
\text { ment }\end{array}$ & $\left\{\begin{array}{c}117(25 \cdot 74 \\
\text { gals. }) \\
0 \cdot 160 \\
(0 \cdot 035 \text { gal. })\end{array}\right.$ & $\begin{array}{c}145(3 \mathrm{I} \cdot 9 \\
\text { gals.) } \\
0 \cdot 142 \\
(0 \cdot 03 \mathrm{I} \text { gal. })\end{array}$ \\
\hline 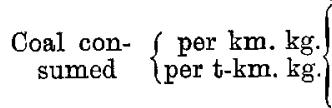 & $\begin{array}{l}\text { No } \\
\text { measure- } \\
\text { ment }\end{array}$ & $\begin{array}{l}\text { No } \\
\text { measure- } \\
\text { ment }\end{array}$ & $\begin{array}{l}\text { No } \\
\text { measure- } \\
\text { ment }\end{array}$ & $\left\{\begin{array}{c}15 \cdot 4 \\
(33 \cdot 95 \mathrm{lb}) \\
0.021 \\
(0 \cdot 046 \mathrm{lb} .)\end{array}\right.$ & $\begin{array}{c}19 \cdot 9 \\
(43 \cdot 87 \mathrm{lb} .) \\
0 \cdot 0195 \\
(0 \cdot 043 \mathrm{lb} .)\end{array}$ \\
\hline $\begin{array}{l}\text { Duration of run, Paris- } \\
\text { St. Quentin, or vice } \\
\text { versa, } 153 \mathrm{~km} .\left(95^{\circ} \mathrm{I}\right. \\
\text { miles) }\end{array}$ & $\begin{array}{l}\text { 1. hour } \\
36 \text { min. }\end{array}$ & $\begin{array}{l}1 \text { hour } \\
35 \text { min. }\end{array}$ & $\begin{array}{l}1 \text { hour } \\
43 \text { min. }\end{array}$ & - & 一 \\
\hline
\end{tabular}

The two last were coal trains from Lens to Paris, following two different routes.

bottom sloping at an angle of $45^{\circ}$. On both sides, auxiliary tanks are provided for briquettes, which are also close at hand.*

Owing to the moderate diameter of their wheels, these engines may be used for every kind of service; they negotiate heavy goods as well as fast passenger trains. This has proved a great

* A description of this tender will be found in Revue generale des Chemins de fer et des Tramways, August 1909, page 99, and Plate xiv. 
convenience on the Nord, where in autumn the goods traffic is enormous, whilst in summer and on holidays a large number of supplementary expresses, all heavy, have to be run. The figures in Table 5 give a fair idea of the results obtained.

The two experimental engines, Nos. 3,1101-3,1102, called "Baltic," have been designed in 1911 to haul weights of 400 tons at speeds of 120 kilometres ( 74.6 miles) an hour on level and 95 kilometres $\left(59^{\circ} \circ\right.$ miles) on 5 millimetres ( $\mathrm{I}$ in 200 ) grades. These performances require an indicated power of 2,200 h.p. (2,I 70 b.h.p.).

\section{TABLE 6.}

\begin{tabular}{|c|c|c|}
\hline No. and date of train & No. 5, 29 April 1913 & No. 115, 7 June 1913. \\
\hline Weight of train & 401 & 382 \\
\hline $\left.\begin{array}{r}\text { Average speed on level . } \\
\mathrm{km} . \text { per hour }\end{array}\right\}$ & $110(68 \cdot 35$ miles $)$ & $113\left(70^{\circ} 21\right.$ miles $)$ \\
\hline $\begin{array}{l}\text { Average speed on } 5 \mathrm{~mm} \text {. (I in) } \\
200 \text { ) incline } \mathrm{km} \text {. per hour }\end{array}$ & $94(58 \cdot 4$ I miles $)$ & $94(58 \cdot 4 \mathrm{I}$ miles $)$ \\
\hline 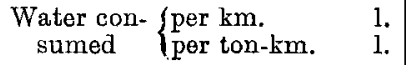 & $\begin{array}{l}117 \text { (25.74 gallons) } \\
0^{\circ} 293\left(0^{\circ} 064 \text { gallon }\right)\end{array}$ & No measurement \\
\hline $\begin{array}{ll}\text { Coal con- } & \text { per } \mathrm{km} . \\
\text { sumed } & \mathrm{kg} . \\
\text { per ton-km. } & \mathrm{kg} .\end{array}$ & $\begin{array}{l}16 \cdot 8(37.04 \mathrm{lb} .) \\
0.042(0.093 \mathrm{lb} .)\end{array}$ & No measurement \\
\hline $\begin{array}{c}\text { Duration of run, Paris-Calais } \\
298 \mathrm{~km} .(185 \cdot 2 \text { miles) }\end{array}$ & $\begin{array}{l}3 \text { hours } 16 \text { min. (in- } \\
\text { cluding } 5 \text { min. stop } \\
\text { at Abbeville) }\end{array}$ & - \\
\hline $\left.\begin{array}{c}\text { Duration of run, Paris-St. } \\
\text { Quentin } 153 \mathrm{~km} .\left(95^{\circ} \text { I miles }\right)\end{array}\right\}$ & - & 1 hour 35 min. \\
\hline
\end{tabular}

The engine is carried on two bogies and six-coupled wheels of 2.040 metres ( 6 feet $8 \cdot 3$ inches) diameter, Fig. 10, Plate 18 . The lateral play of the front bogie is 50 millimetres ( $\mathrm{r} \cdot 97$ inch), and of the rear bogie 120 millimetres $\left(4^{\cdot} 7^{2}\right.$ inches). The principal dimensions are :--

\begin{tabular}{|c|c|c|}
\hline Grate area & . & 4.28 square metres $(46 \cdot 07$ square feet) \\
\hline Heating surface & . & 316.08 square metres $\left(340^{\circ} 2\right.$ square feet) \\
\hline Superheating surface & & 70.00 square metres $(753.5$ square feet) \\
\hline $\begin{array}{l}\text { Diameter and stroke, } \\
\text { pressure cylinders }\end{array}$ & & \}$_{\text {millimetres }\left(25^{\circ} 20 \text { inches }\right)}^{450 \text { millimetres }}$ \\
\hline
\end{tabular}


Diameter and stroke, lowpressure cylinders.

Woigbt, empty

" in working order.

" adhesive . .

\author{
$\{620$ millimetres $(24 \cdot 4 \mathrm{I}$ inches $)$ by 730 \\ - $\{$ millimetres $(28 \cdot 74$ inches) \\ - 103,200 kilograms $(227,5$ 10 lb. $)$ \\ - 113,010 kilograms $(249,140 \mathrm{lb}$.) \\ - 55,510 kilograms ( $23,380 \mathrm{lb}$.)
}

The two low-pressure cylinders inside the frames are, owing to their large diameter, one in front of the other, the distance between their axis being 385 millimetres ( $15 \cdot 2$ inches) only.

\section{TABLE 7.}

\begin{tabular}{|c|c|c|}
\hline No. and date of train & No. 5, 26 Feb. 1914 & No. 115, 28 Feb. 1914 \\
\hline Weight of train . tons & 430 & 356 \\
\hline $\begin{array}{r}\text { Average speed on level } \\
\mathrm{km} . \text { per hour }\end{array}$ & $110(68 \cdot 35$ miles $)$ & $112\left(69^{\circ} 56\right.$ miles $)$ \\
\hline $\begin{array}{cc}\text { Average speed on } 5 \mathrm{~mm} \text {. (I in } \\
200 \text { ) incline } & \mathrm{km} \text {. per hour }\end{array}$ & $90\left(55 \cdot 9^{2}\right.$ miles $)$ & $90\left(55^{\circ} 9^{2}\right.$ miles $)$ \\
\hline $\begin{array}{ll}\text { Water con- } \\
\text { sumed }\end{array} \begin{cases}\text { per } \mathrm{km} . & 1 . \\
\text { per ton-km. } & 1 .\end{cases}$ & $\begin{array}{c}118\left(25^{\circ} .96 \text { gallons }\right) \\
0.275 \text { (0.06I gailon })\end{array}$ & No measurement \\
\hline 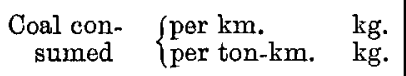 & $\begin{array}{c}19 \cdot 2(42 \cdot 33 \mathrm{lb} .) \\
0.0446(0.098 \mathrm{lb} .)\end{array}$ & No measurement \\
\hline $\begin{array}{l}\text { Duration of run, Paris-Calais) } \\
298 \mathrm{~km} \text {. ( } \mathrm{r}^{8} 5^{\circ} 17 \text { miles) }\end{array}$ & $\begin{array}{l}3 \text { hours } 15 \text { min. (in- } \\
\text { cluding } 5 \text { min. stop } \\
\text { at Abbeville) }\end{array}$ & - \\
\hline $\begin{array}{l}\text { Duration of run, Paris-St. } \\
\text { Quentin } 158 \mathrm{~km} .\left(95^{\circ} \circ \text { miles }\right)\end{array}$ & 一 & 1 hour $36 \mathrm{~min}$. \\
\hline
\end{tabular}

The tender, carried on two bogies similar to the engine bogies, weighs, empty, 25,210 kilograms (55, Eoo lb.) and holds 26 cubic metres $(918.2$ cubic feet) of water and 7 tons of coal. Table 6 gives the results obtained.

It was not thought advisable to build more Baltics before a longer experience; for this reason 20 Pacifics, Fig. 11 (page 402), began service at the end of 1912 with same diameter of wheels that the Atlantics had, but with a greater power and more adhesive weight. The principal dimensions of these Pacifics are given in Table 3 (page 388).

One peculiarity of these engines is the use of by-passes on their high-pressure cylinders instead of air relief-valves. After the results of experiments on the first of these engines, the section of 
the steam pipes, the length of ports of high-pressure cylinders, and the travel of valves have been increased, with a notable gain of power.

Two of the best performances, shown in Table 7 , may be compared with the Baltic's.

The indicated power in regular working attains 1,900 h.p. to 2,000 h.p. (1,972 b.h.p.); 2,120 h.p. (2,090 32 b.h.p.) has been registered once. With a train of 422 tons the speed has been increased from 35 kilometres ( $2 \mathrm{I}^{\cdot} 7$ miles) to 92 kilometres $\left(57^{\circ} 2\right.$ miles) an hour on the 5 millimetres ( $\mathrm{I}$ in 200) grade from St. Denis to Goussainville. On the 8 millimetres ( $\mathrm{I}$ in 125 ) grade from Marquise to Caffiers, ${ }^{*} 8$ kilometres ( 4.97 miles) long, the speed fell from 104 kilometres $(64 \cdot 6$ miles) to only 75 kilometres $(46 \cdot 6$ miles) an hour, with the same train.

As regards superheating, it has been adopted for all recent Nord engines, and will be continued in future engines; with steam temperatures of $300^{\circ}$ to $340^{\circ} \mathrm{C}$, no undue expenses for repairs have been experienced. The Nord engineers are of opinion that superheating and compounding must be combined.

The author cannot conclude better than by reproducing the terms of a letter from M. Asselin, Chief Engineer of the Nord Railway, in which his experience is recorded in a perfectly clear and definite manner.

“ Until 1904 our fast engine was an Atlantic without superheater, four-cylinder compound with a horse-power of 1,400 h.p.(1,380 b.h.p.).

"The first step was to increase the power of these Atlantics by the addition of a superheater. Although taking heavier trains, these engines with superheaters showed an economy of at least $1 \cdot 5$ kilogram $(3 \cdot 3 \mathrm{lb}$.) of coal per kilometre $(0 \cdot 62 \mathrm{mile})$.

"The second step was to build Pacifies of about 1,900 h.p. ( 1,873 b.h.p.). It is remarkable how these Pacifics proved economical. With the same weights they consume practically the same quantity of coal as the Atlantics with superheaters; and with heavier weight than the Atlantics could manage without superheaters they burn less coal.

* See profiles in Proceedings, I.Mech.E., 1904, Plates 55 and 56. 
"I don't mention our two Baltic engines, which are mere experiments. I cannot as yet consider any extension of that type of engine. As regards power they are far in advance of the Pacifics, but far less economical. However, before long I shall be obliged to design locomotives more powerful than the present Pacifics. The weight of our fast trains, which did not exceed 300 tons with the Atlantics without superheaters, attains to-day regularly 400 tons, and frequently up to 450 tons. I must very soon examine the possibility of hauling 500-ton trains with the actual speeds.

"Will the new engines be Pacifics or Baltics? I cannot say. But it will be necessary to increase the boilers of the present Pacifics, their grate area, and the diameter of the cylinders. The size of the boiler is limited chiefly by the weight allowed to each axle by the permanent way department.

"To enlarge the grate area, the length of the grate will be increased to $3 \cdot 50$ metres (I I feet $5 \cdot 8$ inches) or $3 \cdot 70$ metres (I 2 feet I. 7 inch). Contrary to the practice of other French railways, I am personally in favour of the narrow fire-box contained between the frames. The wide fire-boxes were not a success with us, the management of the fire being too laborious. Consequently, grate areas of the Nord express locomotives are smaller than on locomotives of other companies. But as firing is easier we reckon, right or wrong, that this largely compensates the advantage of a wide fire-box with a larger grate area.*

"Our latest experiments were particularly interesting in proving the following points : To design an express locomotive at the same time economical and powerful, all drop of pressure by wire-drawing between the boiler and the low-pressure cylinders must be avoided, ports of high-pressure and low-pressure cylinders must be as large as possible, steam-pipes from boiler to bigh-pressure cylinders, and from high-pressure to low-pressure cylinders, must be of ample section. Lastly, the low-pressure valve motion must be such as to reduce wire-drawing.

* Reference can be made to Mr. G. J. Churchward's Paper on "Large Locomotive Boilers" (Proceedings, I.Mech.E., March, 1906, page 165). 
"In designing a new locomotive, as must be done before long, we will keep in view these desiderata."

\section{Paris-Orléans.}

Since 1904 the Paris-Orléans Railway has ordered 100 Pacifics with 1.850 metre ( 6 feet 0.8 inch) wheels (Nos. 4501-4600), and 90 with 1.940 metre ( 6 feet $4 \cdot 3$ inches) wheels (Nos. 3501-3590), Fig. 12, Plate 19. All are four-cylinder compounds; 30 of the first

\section{Fig. 13.-Half Plan of Firc-box. ("Pacific" Paris-Orléans.)}

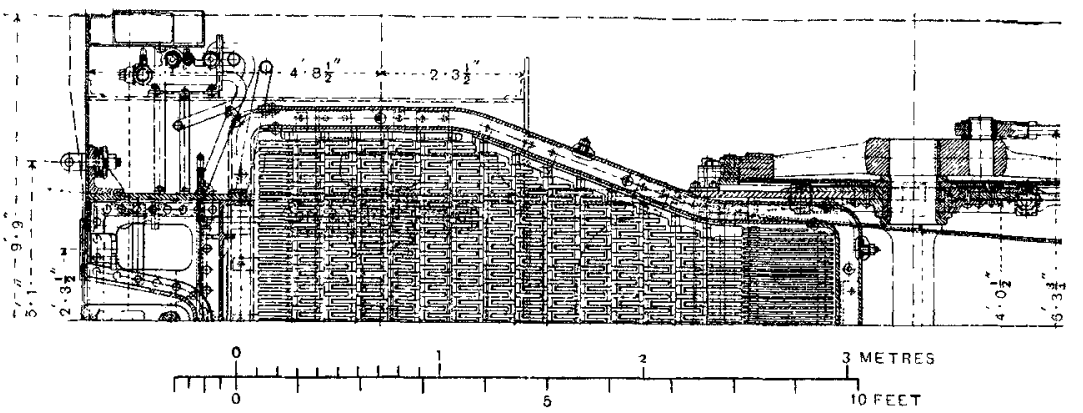

series and 70 of the last have Schmidt superheaters with enlarged high-pressure cylinders.*

The shape of the fire-box is quite peculiar ; it extends over the back trailing wheels, but is contained between the last pair of drivers, Fig. 13, the object being to avoid a shallow box. Reports of the working of this style of fire-box are quite satisfactory. Owing to the great length of the tubes, $5 \cdot 900$ metres (I 9 feet 4 inches) between plates, plain ones without ribs have been adopted, with an outside diameter of 55 millimetres $(2 \cdot 17$ inches $)$. The necessity of increasing the diameter of very long tubes is obvious; but the reason why they are not of the Serve system is not evident. It may be that a sufficient heating surface being obtained with plain

* An account of experiments on the superheaters by M. P. Conte has been published in the Revue Génerale des Chemins de fer et des Tramuays in June, 1912. 
ones, it is better to avoid the increase in cost and weight of the ribbed tubes.

Piston-valves are used on the high-pressure cylinders, and flat valves on the low-pressure, even with superheated steam, and no trouble is reported. The main dimensions of these engines will be found in Table 3 (pages 388-9).

They have six-wheeled tenders holding 20 cubic metres (706. 3 cubic feet) of water and 6 tons of coal.

Indicator diagrams on the superheating Pacifics made apparent a too high compression in the high-pressure cylinders, although the clearance was 13 per 100 . This clearance being enlarged to the mean value of 20 per 100 for both sides, a smoother running was obtained without any increase of steam consumption.* Experiments with fast and heavy trains showed an indicated power up to 2,180 h.p. (2,099.5 b.h.p.), and 1,266 h.p. ( 1,208 b.h.p.) on the draw-bar behind the tender.

An interesting comparison was made in actual running of twenty Pacifics without, and of fifteen with, superheaters, taking the same trains in turns. The mean coal consumption per 100 tonkilometres was in winter, including steam heating of the trains :-

3.92 kilograms $(8.64 \mathrm{lb}$.) for engines without superheaters.

3.51 kilograms $(7 \cdot 74 \mathrm{lb}$.) for engines with superheaters.

and in summer respectively:-

3.53 kilograrns $\left(7^{\circ} 7^{8} \mathrm{lb}\right.$.) and 3.17 kilograms $(6.99 \mathrm{lb}$.$) .$

These figures show an economy averaging 19 per cent. in favour of the superheater.

Special experiments on one engine with superheater showed a consumption of $0 \cdot 97$ kilogram ( $2 \cdot 14$ lb.) to $1 \cdot 12$ kilogram $(2 \cdot 47 \mathrm{lb}$.) of coal per indicated horse-power per hour. One kilogram of coal evaporated from $7 \cdot 87$ kilograms ( $17 \cdot 4$ lb.) to $6 \cdot 82$ kilograms ( $15.0 \mathrm{lb}$ ) of water, with rates of combustion of 299 kilograms $\left(659^{\circ} 2\right.$ lb.) to 430 kilograms ( $948^{\circ} \circ \mathrm{lb}$ ) ) per square metre (10.76 square feet) of grate an hour.

* Compare Mr. G. Hughes's opinion, who advocates shorter periods of compression in preference to increased clearance volume (Proceedings, I.Mech.E., March, 1910, page 401). 
M. P. Conte (in the Paper already mentioned in the footnote on page 409) gives an interesting record of the coal consumption of engines hauling the Paris-Bordeaux fast trains in successive years, as shown in Table 8.

TABLE 8.

\begin{tabular}{|c|c|c|c|c|}
\hline \multirow{2}{*}{ Date. } & \multirow{2}{*}{ Type of Engine. } & \multirow{2}{*}{$\begin{array}{l}\text { Weight of } \\
\text { Train. }\end{array}$} & \multicolumn{2}{|c|}{$\begin{array}{c}\text { Coal consumed from Paris } \\
\text { to Tours. }\end{array}$} \\
\hline & & & $\begin{array}{l}\text { Per ton of } \\
\text { Train. }\end{array}$ & Total. \\
\hline 1897 & Forquenot, 2-4-2 & $\begin{array}{c}\text { Tons } \\
175\end{array}$ & $\left\{\begin{array}{l}18 \cdot 48 \mathrm{~kg} \\
\left(40^{\circ} 74 \mathrm{lb} .\right)\end{array}\right.$ & $\begin{array}{l}3,235 \mathrm{~kg} \\
(7,130 \mathrm{lb})\end{array}$ \\
\hline 1902 & 4-cyl. compound, 4-4. . & 219 & $\left\{\begin{array}{l}15 \cdot 63 \mathrm{~kg} . \\
\left(34^{\circ} 46 \mathrm{lb} .\right)\end{array}\right.$ & $\begin{array}{l}3,424 \mathrm{~kg} . \\
(7,549 \mathrm{lb} .)\end{array}$ \\
\hline 1906 & Atlantic, 4-cyl. compound . & 234 & $\left\{\begin{array}{l}12.83 \mathrm{~kg} . \\
(28.28 \mathrm{lb} .)\end{array}\right.$ & $\begin{array}{l}3,002 \mathrm{~kg} . \\
(6,6 \mathrm{I} 8 \mathrm{lb} .)\end{array}$ \\
\hline 1911 & $\left\{\begin{array}{c}\text { Pacific, without superheater } \\
\text {, with }\end{array}\right.$ & 340 & $\left\{\begin{array}{c}11 \cdot 28 \mathrm{~kg} . \\
(24 \cdot 87 \mathrm{lb} .) \\
10 \cdot 54 \mathrm{~kg} . \\
(23 \cdot 24 \mathrm{lb} .)\end{array}\right.$ & $\begin{array}{l}3,835 \mathrm{~kg} . \\
(8,454 \mathrm{lb} .) \\
3,583 \mathrm{~kg} . \\
(7,899 \mathrm{lb} .)\end{array}$ \\
\hline
\end{tabular}

The 340-ton trains hauled by Pacifics are fitted with Stone's lighting system, which increases the coal consumption slightly. It is well worthy of remark that in a period of 14 years, although the weight of the train has been doubled, the coal consumption has remained nearly the same.

Midi.

During the last decade the Midi Railway has added to its stock the following numbers:--

In 1905, 6 Atlantics, Nos. 1911-1916, 4-cylinder compounds, similar to the ten engines mentioned in the 1904 Paper (page 333); four of these engines will receive a Schmidt superheater.

In 1906-1907, 14 other Atlantics, Nos. 1921-1934, with a longer grate, 3.08 square metres $(33.2$ square feet) instead of $2 \cdot 78$ square metres $(29.9$ square feet), and same cylinders 340 
millimetres ( 13.39 inches) and 560 millimetres $(22.05$ inches) by 640 millimetres $(25 \cdot 20$ inches $)$.

In 1908-1910, 16 Pacífics, Nos. 3001-3016, 4-cylinder compounds, with the following dimensions:-

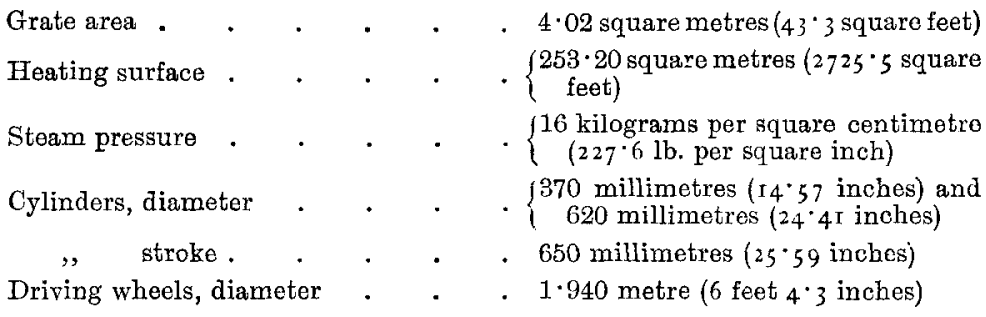

In 1910, 4 similar Pacifics, Nos. 3051-3054 with the addition of a Schmidt superheater of $60 \cdot 88$ square metres $\left(655^{\circ} 3\right.$ square feet), reducing the proper heating surface to $216 \cdot 29$ square metres $(2,328 \cdot \mathrm{I}$ square feet), this proportion being more ample than in many cases already mentioned; the diameter of the high-pressure cylinder has been enlarged to 400 millimetres ( $15 \cdot 8$ inches).

In 1910-1912 a new type came in service of 4-6 engines Nos. 3501-3516, where advantage was taken of the superheater to reduce the boiler pressure to 12 kilograms per square centimetre ( $70.7 \mathrm{lb}$. per square inch), and to revert to simple expansion in two cylinders only, of 590 millimetres $\left(23^{\circ} 2\right.$ inches) by 640 millimetres ( $25 \cdot 2$ inches), Fig. 14, Plate 19. The diameter of wheels is reduced to 1.750 metre ( 5 feet 8.8 inches); the principal other dimensions will be found in Table 2 (page 387 ).

Owing to the good results obtained from these engines, four Pacifics on the same plan, Nos. 3101-3104, have been designed, and are in course of construction, with a boiler pressure of 13 kilograms per square centimetre ( $184^{\circ} 9 \mathrm{lb}$. per square inch), two cylinders of 630 by 650 millimetres $\left(24^{\circ} 80\right.$ by $25^{\circ} 59$ inches $)$, and wheels of $1 \cdot 940$ metre ( 6 feet $4^{*} 3$ inches), Table 3 .

We may mention here, as used for express trains on mountain lines, 6 tank-engines, Nos. 4501-4506, put in service in 1913, with 4-coupled axles and bogie, having the following dimensions :Grate area . $\left\{\begin{array}{c}3 \cdot 10 \text { square metres }(33 \cdot 37 \text { square } \\ \text { feet) }\end{array}\right.$ 
Heating surface . . . . $\left\{\begin{array}{c}163 \cdot 16 \text { square metres }(1756 \cdot 2 \text { square } \\ \text { feet })\end{array}\right.$

Superheating surface. . . $\{45 \cdot 26$ square metres $(487 \cdot 12$ square

Boiler pressure . . . $\quad\{12$ kilograms per square centimetre

(170.68 lb. per square inch)

Cylinders (two), diameter . . . 630 millimetres (24.80 inches)

", stroke. . . . 640 millimetres (25.20 inches)

Diameter of wheels . . . . 1.600 metre ( 5 feet 2.9 inches)

Weight, empty . . . . . 74,000 kilograms $(72 \cdot 8$ tons $)$

" in working order . . . 93,500 kilograms ( 92 tons)

" adhesive . . . 70,500 kilograms $\left(69^{\circ} 4\right.$ tons $)$

\section{TABLE 9.}

\begin{tabular}{|c|c|c|c|c|}
\hline \multirow{2}{*}{ Engines. } & \multirow{2}{*}{$\begin{array}{l}\text { Average } \\
\text { mileage } \\
\text { per month. }\end{array}$} & \multirow{2}{*}{$\begin{array}{c}\text { Average } \\
\text { weight } \\
\text { of train } \\
\text { alone. }\end{array}$} & \multicolumn{2}{|c|}{ Coal consumed. } \\
\hline & & & Per km. & $\begin{array}{l}\text { Per ton-km. } \\
\text { of train alone }\end{array}$ \\
\hline$\left\{\begin{array}{c}\text { Simple superheaters, } \\
\text { Nos. } 3501-3516\end{array}\right\}$ & $\begin{array}{c}8,262 \mathrm{~km} . \\
(5,133 \mathrm{miles})\end{array}$ & $\left\{\begin{array}{c}\text { Tons. } \\
225\end{array}\right.$ & $\begin{array}{l}11.646 \mathrm{~kg} \\
(25.662 \mathrm{lb} .)\end{array}$ & $\begin{array}{l}0.0522 \mathrm{~kg} \\
(0.1 \mathrm{I} 5 \mathrm{lb})\end{array}$ \\
\hline$\left\{\begin{array}{cc}\text { 4-cyl. compound non- } \\
\text { superheaters, } \\
3001-3016\end{array}\right.$ & $\begin{array}{c}8,181 \mathrm{~km} \\
\left(5,083^{\circ} 4 \text { miles }\right)\end{array}$ & 225 & $\begin{array}{l}13.866 \mathrm{~kg} . \\
(30.57 \mathrm{lb} .)\end{array}$ & $\begin{array}{l}0.0623 \mathrm{~kg} . \\
(0.137 \mathrm{lb})\end{array}$ \\
\hline$\left\{\begin{array}{c}\text { 4-cyl.superheater,Paci- } \\
\text { fics, Nos. } 3051-3054 .\end{array}\right\}$ & $\begin{array}{c}8,150 \mathrm{~km} \\
\left(5,064^{\circ} 2 \mathrm{miles}\right)\end{array}$ & 255 & $\begin{array}{l}14 \cdot 100 \mathrm{~kg} . \\
(3 \mathrm{I} \cdot 09 \mathrm{lb} .)\end{array}$ & $\begin{array}{l}0.0563 \mathrm{~kg} . \\
(0.124 \mathrm{lb} \text {.) }\end{array}$ \\
\hline$\left\{\begin{array}{c}\text { 4-cyl. compound non- } \\
\text { superheater, Pacifics, } \\
\text { Nos. 3001-3016 }\end{array}\right\}$ & $\begin{array}{c}8,140 \mathrm{~km} \\
(5,058 \mathrm{miles})\end{array}$ & \} 252 & $\begin{array}{l}14 \cdot 616 \mathrm{~kg} . \\
(32 \cdot 22 \mathrm{lb} .)\end{array}$ & $\begin{array}{l}0.0591 \mathrm{~kg} . \\
(0.130 \mathrm{lb} .)\end{array}$ \\
\hline
\end{tabular}

The author is indebted to M. Herdner, chief engineer of the Midi, for the comparison of simple superheaters and compound non-superheaters, Table 9. This comparison results from practical working of the same trains during periods of nine to ten months, and is specially interesting in the second case, where similar Pacifics ran in parallel. In the first case, the Pacifics weighing 90 tons, with their grate area of 4.02 square metres $\left(43^{\circ} 3\right.$ square feet) ran against 4-6 engines of $76 \cdot 3$ tons, with grate of 2.78 square metres $\left(29^{\circ} 9\right.$ square feet), which were probably appropriated to the not very heavy trains. 
In his elaborate Paper, "Compounding and Superheating in Horwich Locomotives"* Mr. G. Hughes comes to similar conclusions.

As pointed out by Mr. J. A. F. Aspinall, $\uparrow$ and by Mr. G. Hughes in his 1910 Paper, the coal bill is only one item of expense in locomotive working, although the rise in the price of coals makes it more and more important; the economy of first cost in the case of two-cylinder simple engines must be taken into account. It will be of great interest to analyse in the long run as far as possible the new practice of the Midi.

The above descriptions make apparent the large increase in the power of express locomotives, which is characteristic of recent constructions; nevertheless, a further increase will be required in a near future. To meet the severe requirements of traffic, larger boilers have been designed and fitted with superheaters. This state of affairs seems to be the same in Great Britain and in France. In both countries special experiments as well as ordinary practice have proved that superheating confers an important increase of power without causing trouble or undue expense. Another point on which experts agree is that superheating alone is equal to or even better than compounding with saturated steam.

One point that seems open to further discussion is whether superheating and compounding must be superposed. In general, French practice as regards express engines is in favour of this superposition, with the interesting exception of the Midi Railway.

The Paper is illustrated by Plates 17 to 19 and 8 Figs. in the letterpress, and is accompanied by an Appendix.

* Proceedings, I.Mech.E., March, 1910, page 399.

† Ibid, 1900, page 408. 


\section{APPENDIX.}

Descriptions and tracings of some of the locomotives mentioned above will be found in the following periodicals :-

Est, No. 3166 (superheating in two stages), The Engineer, 14 Oct. 1910 , page 416.

Paris-Lyon-Méditerranée, Nos. 2601-2605, Engineering, 24 Nov. 1905, page 704;

-, Pacific, Nos. 6101-6171, Engineering, 8 Sep. 1911, page 317, The Engineer, 29 Sep. 1911, page 322 ;

-, Pacific, No. 6001, Engineering, 16 March 1913, page 666 ; The Engineer, 24 Oct. 1913, page 430.

Nord, Atlantic, Nos. 2641-2675, Engineering, 12 Oct. 1906, page 488 ;

--, Baltic, The Engineer, 10 Feb. 1911, page 149, and 1 Sep. 1911, page 241.

Paris-Orléans, Pacific, No. 4501, Engineering, 9 and 30 April 1909 , pages 409 and 588.

Midi, Pacific, Nos. 3001-3011, The Engineer, 16 Sep. 1910, page 311.

\section{Discussion.}

The Chairman (Mr. Michael Longridge, Vice-President) said that before asking the members to thank the author for his interesting Paper, he desired to say how very much they appreciated the information that was contained in it. Personally, he could remember the Northern Railway of France when the express trains were run by Crampton locomotives which had a single driving wheel situated behind the fire-box and comparatively small adhesion. The great advantage claimed for that locomotive, as far as he could remember, was that it had a low centre of gravity, and there were no coupling-rods. Engineers had since learnt by experience that coupling-rods were not such a tremendous evil 
(Mr: Michael Longridge.)

as at one time was thought to be the case, and they learnt from better education that a very low centre of gravity was not such a very desirable thing as it was once supposed to be. One of the points in the Paper which he hoped would be discussed was the advantages of compounding and superheating, not by themselves, but in relation to the kind of traffic which the engines had to work, and he hoped attention would also be directed to the boilers of the enormous locomotives, which seemed to him to be the most vulnerable point about them. He asked the members to express in the usual manner their thanks to the author for his interesting Paper.

The resolution of thanks was carried with acclamation.

Mr. HENRY Fow afraid it was difficult to discuss the Paper without covering the whole of the ground of the difference of locomotive practice in France and England. He desired, in the first place, to endorse what the author had said with regard to superheating. Practically no passenger locomotive was built in Kngland at the present day unless it was fitted with some type of superheater. The author had not dealt with details. There was one difficulty, however, which he (Mr. Fowler) had dealt with at another Institution early this year, that he knew to be a very real one on a large number of railways, more particularly in the United States and to a less degree in England. This was the difficulty of keeping the large tubes of the superheater tight. Speaking from experience on the Midland Railway, this trouble was met with in tubes of considerable length. In the locomotives on the Midland, where the boilers were, comparatively speaking, short, practically no trouble was experienced, but in the boilers of some engines taken over from a railway company absorbed by the Midland, and in which the tubes were about 15 feet long, very considerable difficulty had been experienced in keeping the tubes tight. That, he thought, was largely due to the fact that the water was exceptionally bad, and, once leakage took place through large tubes with bad water, it seemed a very difficult matter to stop it. 
He was sure all the members had listened with great interest to what the author had said with regard to dispensing with dampers in the boilers which had been superbeated on the French railways. That was being tried on many railways in England, and so far no trouble had, he believed, been experienced. If it were possible to get rid of the damper with its attendant mechanism it would no doubt be a very considerable advantage. Very little had been done in England with regard to the superheating of compound locomotives. He believed the Great Central and the Midland were the only railway companies who had done anything in the matter, because, as was well known, the compound locomotive had never obtained the same hold in England as it had done in France. He believed that in future the locomotive in England as well as in France would be a 4-cylinder superheated compound.

He was rather surprised at the statement made with regard to the P.L.M. that the drop between the boiler and the steam-chest amounted frequently to $42 \frac{1}{2} \mathrm{lb}$. per square inch. That was entirely against the experience on the Midland Railway. He thought it must be due to very tortuous passages through which the steam had to go, because it had been found that the usual retardation, owing to the passage through which the superheated steam had to go, was more than made up for by the high fluidity of the superheated steam.

The author stated on the first page of the Paper that the Atlanties were not likely to be reproduced. He (Mr. Fowler) desired to call attention to the fact that during the last week he had received a photograph of an Atlantic engine which had been turned out on the Pennsylvania Railroad, by Mr. A. W. Gibbs, the Chief Mechanical Engineer, who stated he believed there was still a very large field of work for the four-coupled engine. With regard to the Chairman's remark that coupling-rods were not such an evil as was sometimes thought to be the case, this idea was probably due to the fact that engineers had got used to the trouble. There was not the slightest doubt that no engine ran so nicely or freely as that with single driving wheels, but the adhesion was of course deficient. 
M. Albert Herdner (Chemins de fer du Midi), speaking in French, said that his first remark on Mr. Sauvage's interesting Paper would bear on Table 9 (page 413). In the two last lines of this Table was an error which he wished to rectify, namely twocylinder Pacifics were compared to four-cylinder engines. This was erroneous-as all present Pacifics were four-cylinder engines, and a comparison could only be made between Pacifics (series 3051 to 3054) which were compound and worked with superheated steam, and Pacifics (series 3001 to 3016 ) which were four-cylinder compound and worked with saturated steam.* With reference to such a comparison there would be another argument to put forward. The consumption per kilometre for superheated steam was $14 \cdot 1 \mathrm{~kg}$. and $14 \cdot 616 \mathrm{~kg}$. for saturated steam, so that the difference was only half a kilogram per kilometre. This referred to a mean consumption bearing on observations made during nine or ten months, as the author himself had said. In reality, this difference had varied considerably. It was one kilogram at the start, but after a time it was found to decrease by degrees, this being due, without doubt, to drivers neglecting to clean the superheater. They had been made to clean it regularly and the difference had again risen; but this result might be partially attributed to a modification which had been introduced in the exhaust at about the same time. The difference had never been more than one kilogram, in fact; and he attributed this low result to the engines referred to having insufficient superheaters-not that their superheating area was too small (it stood at 15 square metres per square metre of grate area) but because the sectional area, which the superheater presented as an opening for the gases, was not a large enough fraction of the total opening.

From experience gained with the different types of engines using superheated steam, it seemed that in order to have efficient superheating it was necessary that 45 per cent. of the gases should go through the superheating tubes, supposing, of course, that the speed of circulation was the same in superheater tubes as in smoketubes. In the engine referred to, this proportion was only 38 per

* This has been corrected by the Author. 
cent., so that, on replacing the tubular plates of these engines, care would be taken to increase the superheating elements from 24 to 28 . The latter figure had been adopted in the new Pacific in course of construction.

As to the difference of opinion, which the author's conclusions seemed to indicate, between the Compagnie du Midi and the other companies, the speaker thought that such a difference was apparent only. His company had never been against compounding so far as it went-far from it; his company had always thought even, that the use of four non-compound cylinders was not justifiahle, and that to build four-cylinder engines was to bring forth at once all the inconvenient points resulting from the complication of the four cylinders without benefiting by the main advantage which this complication gave, that is to say: the possibility of working the engine as a compound engine in every case. Compounding and superheating, he thought, were not the only main factors for economy, and the number of cylinders played its part in the efficiency of an engine. In other words-other things being equal, a two-cylinder engine was mone economical than a four-cylinder one. The first observations concerning this were taken some ten years ago. It was when his company had turned old engines into two-cylinder compounds taking superheated steam, according to the formula applied by M. Mallet to the first compound engine which had run, and had compared these engines with others more or less similar in grate area and having the same number of coupled axles and the same diameter of driving wheels, but having four cylinders, that it was found that the first lot used less steam than the second.

The difference in coal consumption was about one kilogram on 12 to 13 kilograms burnt per kilometre. Of course this might be partly due to other causes besides a difference in the number of cylinders, because the boilers in the two cases were not identical, but the same difference had been established in other cases.

When non-compound, two-cylinder engines, taking superheated steam, were tried on the same service as the Pacific engines to see how they would behave, a difference of over two kilograms per 
(M. Albert Herdner.)

kilometre was observed. In this case, however, it was evident that the two engines could not be compared, since Pacific engines had a grate area of 4 square metres, whereas two-cylinder engines using superheated steam had $2 \cdot 78$ square metres only. More recently, observations had been taken during a six days' trial on two engines, with six wheels coupled and two cylinders, taking superheated steam and working non-compound, two Atlantics working compound with saturated steam and having four cylinders, and two similar Atlantics, but fitted with a superheater. All these engines had the same grate area: $2 \cdot 78$ square metres; but the first were gauged at $12 \mathrm{~kg}$, with driving wheels of 1.75 metre diameter, whereas the Atlantics were ganged at $16 \mathrm{~kg}$. with $2 \cdot 04$ metre driving wheels.

For an ordinary train of about 260 tons the respective consumptions per kilometre were as follows: $13 \cdot 229 \mathrm{~kg}$. for fourcylinder Atlantics using saturated steam; 12.529 for four-cylinder Atlantics taking superheated steam; and $11 \cdot 614 \mathrm{~kg}$. for two-cylinder engines. So that in this case again the two-cylinder engine with superheated steam came out best. He would not, however, conclude that in every case a two-cylinder engine, using superheated steam, must score over a four-cylinder compound using superheated steam, but he had been led to believe that, as it was impossible to apply superheating and double expansion simultaneously to twocylinder engines of high power, the decrease in the number of cylinders made it possible for an appreciable portion of the fuel to be saved, which would have otherwise been lost if double expansion had been wasted on an engine using highly superheated steam.

On the other hand, the cost of upkeep had to be considered. This cost was much higher for four-cylinder engines than for two. A saving of 2,000 francs a year on every engine could easily be realized on shed repairs, apart from workshop repairs, which bore on the boiler principally; and it was evident beforehand that the upkeep of a boiler gauged at 15 to $16 \mathrm{~kg}$. was greater than that of one gauged at 12 to $13 \mathrm{~kg}$. only. Admitting even that the cost of extra fuel for two-cylinder engines would cover the saving in upkeep, there still remained the fact that they were of simpler 
construction, offered less chances to go wrong and could be repaired more quickly. They were moreover easier to run than four-cylinder compounds using superheated steam, which were complicated machines to be handled by expert drivers only. His company had taken great interest in this question, and they were looking into the real value of the advantages and were having Pacifics built, similar to the present Pacifics, but with two instead of four cylinders, and gauged at $13 \mathrm{~kg}$. instead of $16 \mathrm{~kg}$. Their superheated would moreover consist of 28 elements instead of 24. His company were hoping that, though the diameter of their piston was $63 \mathrm{~cm}$., these engines would give satisfaction, and that, as far as coal consumption went, they would not be appreciably inferior to the Pacifics, working compound with superheated steam, and in any case, on the whole, they would be more economical.

Mr. G. V. V. Hutchinson said that the experiment on watertube fire-boxes for locomotives which had been made by the Nord Railway was of great interest to locomotive men. The experiment was not actually referred to in the Paper, but the Baltic type of engine shown in Fig. 10, Plate 18, contained a water-tube fire-box. It would be very interesting to know what the behaviour of those fire-boxes was in practice. Did the boiler which was fitted with the water-tube fire-box make steam better than a boiler fitted with the ordinary fire-box? Did the water-tubes require frequent renewal, and had trouble arisen from leakage of these tubes? One way of increasing the power of the modern locomotive, and at the same time keeping it within limits of size, was to increase the working pressure. He did not know if the ordinary fire-box was capable of taking still higher pressures than those in use at the present time, especially on some of the railways in France; but if the pressure were increased-and it would require to be increased considerably to be of any use-the water-tube fire-box would stand a good chance. If the water-tube fire-box were used in connexion with the ordinary barrel of the boiler, as in the Baltic type of Nord engine, the barrel would have to be made strong enough to withstand the high pressure, which meant that it would have to 
(Mr. G. V. V. Hutchinson.)

be made heavy, and heavy weight was objectionable. In that case a complete water-tube boiler for the locomotive suggested itself. Such a boiler would contain parts of only small diameters. There were a great many mechanical difficulties in the way of producing a practical water-tube boiler for locomotives, but he thought the principle was right, and what was required was careful design and experiment. It was not to be expected that the early designs would solve the problem, but by perseverance he thought an efficient result would be obtained. It was not to be expected either that any railway company would be prepared to stand the expense of experiments of that kind. A suggestion, however, had been made before the Institution that railway companies should subscribe to a common fund for the building of experimental locomotives. If such a fund materialized, he thought it could be put to very good use in producing a practical water-tube boiler for locomotives.

Mr. Eugìne Ronceray said that M. Herdner's remarks with reference to his experiments in connexion with single versus compound locomotives made him (Mr. Ronceray) think that perhaps some of the engineers of British railways, who were certainly fond of simplicity, would be interested in a device which the speaker designed about eighteen years ago; but he was sorry that this mechanism had never been tested in actual practice. At that time he was a draughtsman in the service of a railway company in which compound locomotives were already in favour, and he thought it would be possible to improve the locomotive valve-gear in such a way as to take advantage of the increased pressures which were the results of attempts to increase the boiler power. His aim was to increase the steam expansion and design a gear which did not possess the faults of axrangements commonly known. It was, of course, necessary to do away with all delicate motions and complicated devices used on fixed engines, and he succeded in devising a valve-gear the parts of which were exactly of the same character as those already in use. The cut-off gear, Fig. 15, was arranged along the lines of gears in use for locomotives such 
as the Walschaert, Gooch, etc., but not the Stephenson. The leads both for admission and to exhaust were constant, compression was constant, the only varying elements being admission and expansion,

Fig. 15.-Application of Ronceray's Design to Walschaert Gear.

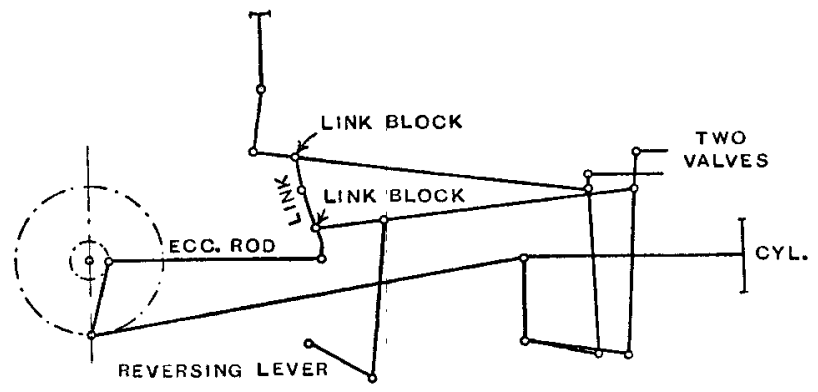

all this being obtained by very simple means and without undue complication. At the same time admission could be obtained from 2 to 80 per cent., while the closing of the steam-ports could be obtained at speeds similar to Corliss engines, no other arrangements

Ftg. 13.-Application of Ronceray's Design to Gooch Gear.

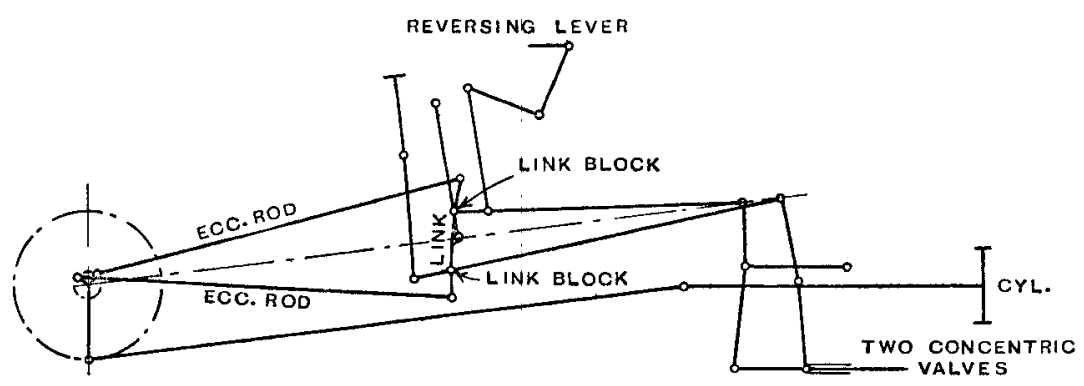

than ordinary valves and levers being used. His first design was for a cylindrical valve, Fig. 16, but he found that this kind of valve met with so many objections from railway engineers at that time that he thought it better to make a second design with a flat valve, Fig. 15, thus avoiding further criticism. Most of the

2 I 2 
(Mr. Eugène Ronceray.)

locomotives in use to-day were fitted with piston-valves, and he understood that no trouble whatever was resulting from this arrangement even when superheated steam was used. He would not have referred to his valve-gear if $M$. Herdner had not spoken as he did, for he thought that compound locomotives were to be adopted universally in future. He felt sure, however, that if this valve-gear proved successful, it would be possible to build simple locomotives as powerful and as economical as compounds. At the same time these would be simpler and cheaper in maintenance.

Professeur Edouaro Sauvage replied in a few words to the observations that had been made. Mr. Fowler had mentioned the high drop of pressure on the P.L.M. engines. A similar experience had been obtained with the engines on the Nord Railway, namely, that when the ports were not quite large enough the drop of pressure was considerable, and care was now taken to design the locomotives with straight and very large passages. That was a point of great importance. Mr. Fowler had also referred to the advantage of the Atlantic type of engine, as used, for instance, on the Pennsylvania Railroad. French engineers would certainly use Atlantic engines if they were able, as was the case on the Pennsylvania Railroad, to have weights of from 25 to 28 tons per axle. With two axles carrying 27 tons an adhesive weight of 54 tons was obtained, nearly equal to the weight on three axles of French engines; the permanent way of French railways would not in any case allow of the use of such heavy weights. M. Herdner had given some very interesting details as to the practice on his line (Chemins de fer du Midi), and the working of the 2-cylinder engines to which he had referred would be watched with great interest. A great deal of advantage seemed to accrue from the simplicity and cheapness of that style of engine.

Mr. Hutchinson had referred (page 421) to the Baltic engines that had been built by the Nord Company. Only two of those engines had been built by way of experiment, and the Nord officials were very reserved in the opinion they expressed in regard to them. They said they were very powerful engines, but rather 
expensive. Mr. Hutchinson was right in pointing out that in that case enlarged fire-boxes had been resorted to. Only two Baltics had been made, one with an ordinary fire-box, and the second with a water-tube fire-box, and it was most unlikely that any further engines of that last type would be constructed. Unfortunately the engine with the water-tube fire-box was not a success, as it required constant repair. Several types of water-tube fire-boxes had been tried by the French companies, but without success.

The remarks made by Mr. Ronceray (page 422) in regard to his now gear which gave variable admission and constant compression were very interesting, and he hoped that gentleman would be more successful in his work than the inventors of other new types of gear. Several kinds of Corliss and drop valves had been tried for locomotives without great success, but there was no reason why a new design should not be more successful. So far as he was aware, no trouble had been experienced in keeping the big tubes for the superheater tight.

\section{Communications.}

Mr. E. L. Ahrovs wrote that he would like to thank the author for keeping English engineers au fait with what their French colleagues were doing. There were one or two questions about which the writer thought a little further information would be of interest.

It would appear from Table 2 (page 387) that Serve tubes were used for the 4-6-0 engines of three companies, but not for those of the Etat and Midi. Herein lay some difference of opinion amongst French engineers. Could it be said in general that the advantages derived from the use of these tubes had been sufficient to warrant their continued use? In England, where they had been tried on a few railways, they were no longer used. On the other hand, all the French Pacific engines, with the exception of those of the Nord, 
(Mr. E. I. Ahrons.)

had plain tubes (Table 3). Would it be the cuse that the increased length of tubes in the Pacifics produced a final temperature of the gases sufficiently low as to render the extra cost of Serve tubes unnecessary, more especially in engines with superheaters?

Of the six illustrations of engines given, only two of them showed the wind-cutting cab fronts, namely, those of the Est and P.L.M. engines. It was noteworthy that, in the case of the engines of the P.L.M., only the cabs were thus shaped, and the old form of wind-cutting engines, in which the smoke-boxes and domes were similarly shaped, had been abandoned. Had it been proved beyond doubt that these wind-cutting devices had been successful in effecting a diminution of resistance? The writer considered that a side wind or a wind upon the "quarter" would cause more train-resistance than a head wind, as the flanges of all the vehicles of the train would be pressed against the rails. For a side wind or head wind at an angle, a wind-cutting cab appeared to offer rather more resistance than a plain cab.

In the P.L.M. valve-gear the admission to the low-pressure cylinder was stated to be always 63 per cent., so that the ratio of volumes of the h.p. and l.p. cylinders would vary for each variation of the point of cut-off in the h.p. cylinders. It would be very interesting if the author would publish in the Proceedings some indicator diagrams from these engines, such as would show the effect of this method of steam distribution, when the h.p. cylinder was cutting off at 88 per cent., and also when the cut-off was, say, 40 per cent.

Mr. E. Cecrl Poultwey wrote that the Paper showed there were in use in France some remarkably fine express locomotives, and that the railways whose locomotives had been mentioned had in use engines of greater power than on the principal railways of Grent Britain. Looking at the locomotives described, from the British point of view they seemed to be more complicated than those used in this country, and this was mainly brought about by the use of four-cylinder compounds having separate valve-gear for the h.p. and l.p. motion. The performance of the Nord 
Pacifics given on page 407 was interesting. So far as he, (Mr. Poultney) understood, the figures seemed to indicate that these engines could maintain 1,900 i.h.p., and, as their heating surface was 2,776 square feet; they could develop 1 i.h.p. for 1.45 of total heating surface. The weight of the engines only in working trim was given as 84 tons, which in turn meant that 1 i.h.p. was developed per 0.044 ton of engine weight. Both figures showed these engines to be of a very efficient design.

Particulars were published in The Engineer (6th February 1914) of the performance of a new type of 4-6-0 express locomotive designed for service on the London and North Western Railway, and known as the "Claughton" class. These engines had four simple cylinders and were superheated; they weighed in working order 77 tons, and had 2,231 square feet of total heating surface. From the data published, it appeared these engines could maintain 1,400 i.h.p., which meant that 1 i.h.p. could be developed per 0.055 ton of engine weight, and that 1.6 square foot of total heating surface would produce 1 i.h.p. The difference in the working steam-pressure of the French engine compared with the English design would in some measure account for the greater power developed per unit of weight and heating surface, but that could not account for the whole difference, a portion of which must be put down to the use of compound cylinders. At the present time, express locomotives equal in power to the French engines described were not required in this country, but when such engines became necessary, it seemed evident from the figures now given that compound superheated locomotives having four cylinders for the sake of balancing would offer the most ready solution of the problem. With regard to the counterweights in the wheels, the photographs showed that the balance-weights of the French engines were placed in quite a different position in the wheels, that is, in relation to the cranks compared to four-cylinder locomotives on English railways. This was a point worthy of consideration.

Mr. W. M. URIE wrote that, referring to the author's remarks on maintenance of locomotives fitted with superheaters, very much 
(Nr. W. M. Urie.)

depended on the efficiency of the mechanical lubricator and quality of oil used. Engines fitted with superheaters were started in June 1910, on the Caledonian Railway, and there were now forty-six superheater locomotives, thirty-four on the Schmidt system and twelve on the Robinson system. Considerable trouble was caused at first by failure of the lubricators, sumetimes through excessive superheat and in other cases by the gearing working the lubricator giving way it the cross-head attachment. These troubles had been overcome by strengthening the parts found defective. It was of the utmost importance that the mechanical lubricator should be kept in perfect order on engines fitted with superheaters, as its failure to lubricate efticiently caused disaster to piston-valves, cylinder piston-rings, etc. 'There were several kinds of mechanical lubricators in use. M. Flamme recently informed the writer that on the Belgian State Railway their experience was much the same as on the Caledonian Railway. He (Mr. Urie) had seen several of their latest types of locomotives when visiting their works at Brussels and Malines, and he noted that the mechanical lubricators were worked with gearing connected to the cross-head, as on British locomotives, exrepting locomotives on the North Eastern and Midland Railways, the geuring in the latter cases being worked from swing link of valve motion.

Mr. Fowler mentioned (page 416) that he experienced trouble in keeping the large superheater tubes tight in the tube-plate. This had also been a trouble on the Caledonian locomotives, but not as yet to a serious extent; it was easily overcome by re-expanding the tubes. Several of the Caledonian locomotives were running without the damper-box and doors covering the superheater elements as an experiment; and as the ends of the elements next to the fire-box were made especially strong, no trouble was expected to arise from overheating, provided the driver and fireman were careful not to overcharge the fire-box. On these engines the pyrometers had also been discarded, on account of their cost and unreliability. 


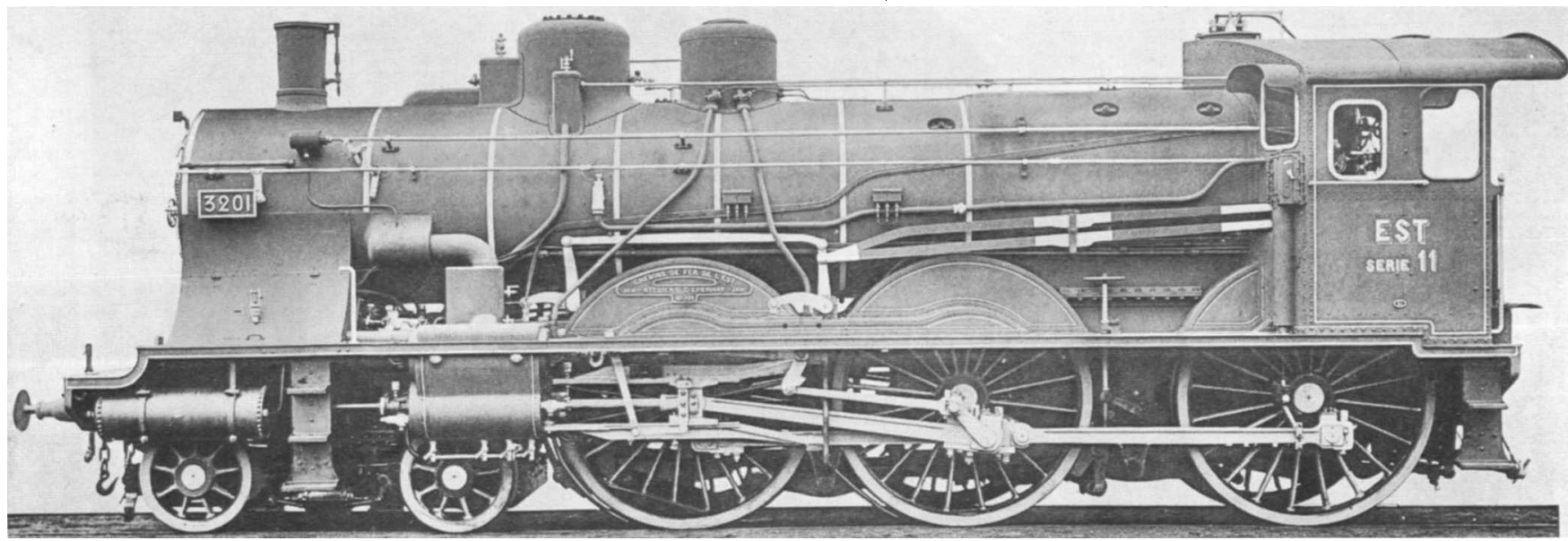

Fig. 5. Nos. 6201-6285, Paris-Lyon-Méditerranée. (No. 6027 las bien altered to 6217.) 
Fig. 7. Nos. 231,011-231,060. Etat. "Pacific" type'.
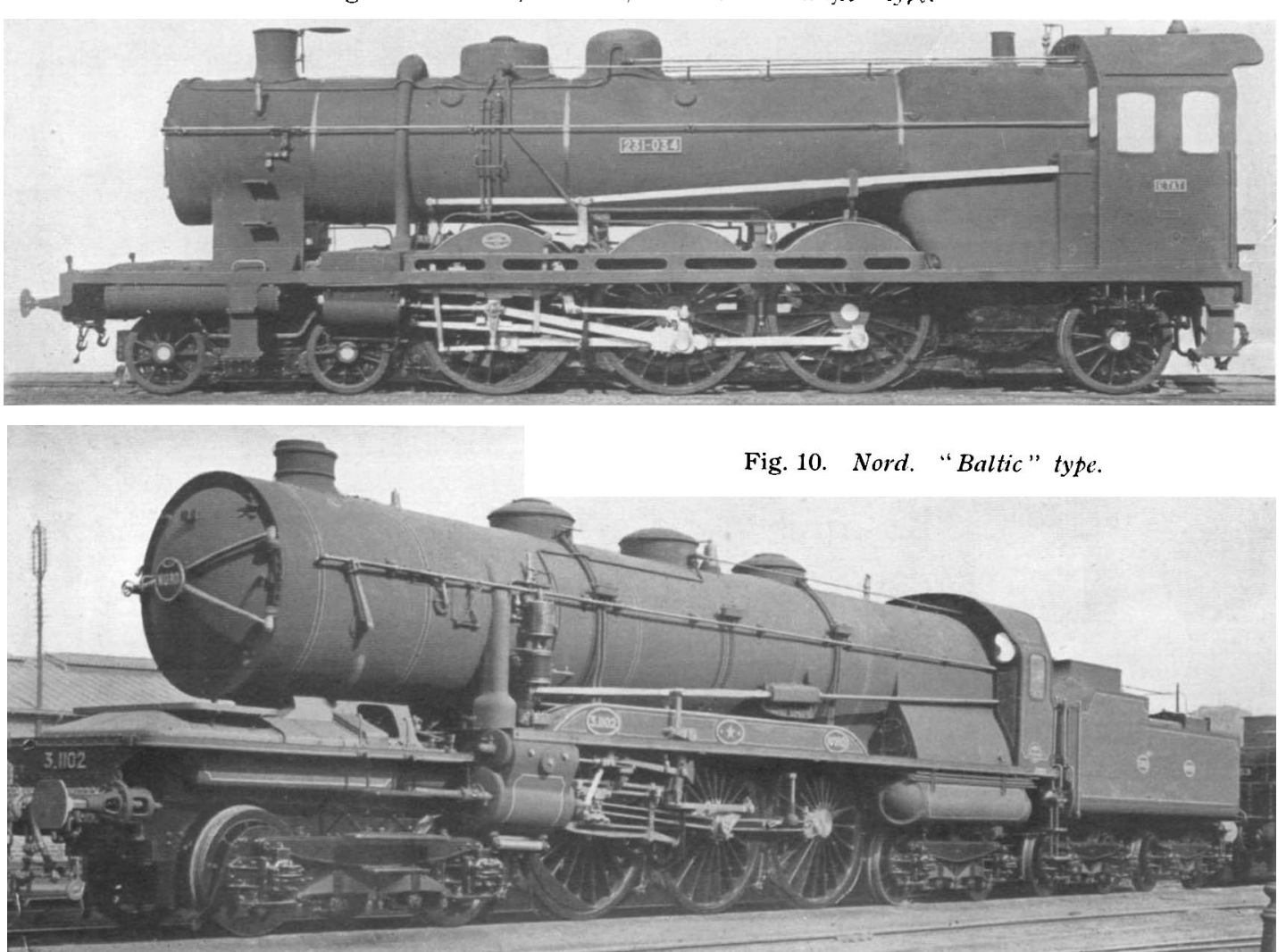

Plale 18. 




